\title{
Sudan: Report on the Final Review of the 2003 Staff-Monitored Program and the 2004 Staff-Monitored Program
}

This paper on the final review of the 2003 staff-monitored program and the 2004 staff-monitored program for Sudan was prepared by a staff team of the International Monetary Fund as background documentation for the periodic consultation with the member country. It is based on the information available at the time it was completed on June 2, 2004. The views expressed in this document are those of the staff team and do not necessarily reflect the views of the government of Sudan or the Executive Board of the IMF.

The policy of publication of staff reports and other documents by the IMF allows for the deletion of market-sensitive information.

To assist the IMF in evaluating the publication policy, reader comments are invited and may be sent by e-mail to publicationpolicy@imf.org.

\author{
Copies of this report are available to the public from \\ International Monetary Fund • Publication Services \\ 700 19th Street, N.W. • Washington, D.C. 20431 \\ Telephone: (202) 6237430 • Telefax: (202) 6237201 \\ E-mail: publications@imf.org • Internet: http://www.imf.org \\ Price: $\$ 15.00$ a copy
International Monetary Fund Washington, D.C.





\title{
INTERNATIONAL MONETARY FUND
}

\author{
SUDAN

\section{Report on the Final Review of the 2003 Staff-Monitored Program (SMP) and the 2004 SMP} \\ Prepared by the Middle East and Central Asia and \\ Policy Development and Review Departments \\ (In consultation with the Finance, Fiscal Affairs, Legal, \\ Monetary and Financial Systems, and Statistics Departments) \\ Approved by Lorenzo L. Pérez and Matthew Fisher
}

June 2, 2004

- $\quad$ Discussions on Sudan's economic performance in 2003 and a program for 2004 took place in Khartoum from February 16 to March 1, 2004. The staff team included Mr. Shabsigh (head), Messrs. Al-Ghelaiqah, Gemayel, and Ilahi, and Ms. Wandwasi (all MCD), and Mr. Hussain (PDR). Mr. Arnason (FIN) joined the latter part of the mission to discuss arrears-related issues, and Mr. Radev (FAD) provided technical assistance on public expenditure management, GFS accounting issues, and fiscal cash management.

- $\quad$ The mission met with Ministers Al-Zubeir Ahmed Al-Hassan (finance and national economy), Abda Yahia El Mahdi (state minister of finance for international cooperation), the central bank Governor Sabir Mohamed Hassan, and other senior Sudanese officials.

- The principal author of this report is Mr. Shabsigh. Contributors included Messrs. Al-Ghelaiqah, Gemayel, Ilahi, Arnason, and Hussain; and Ms. Wandwasi. 


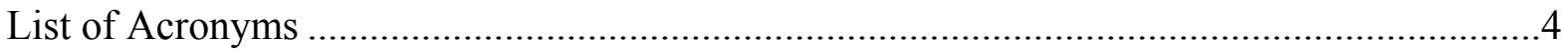

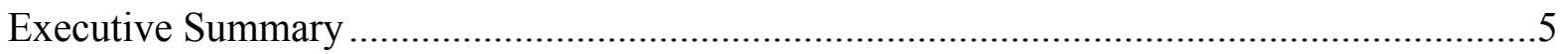

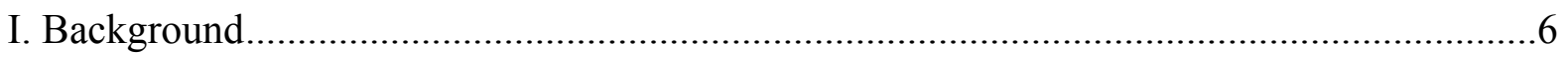

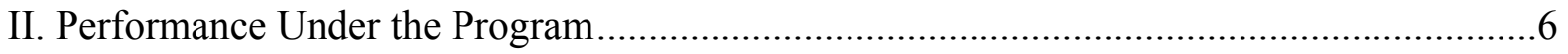

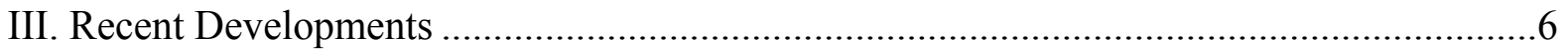

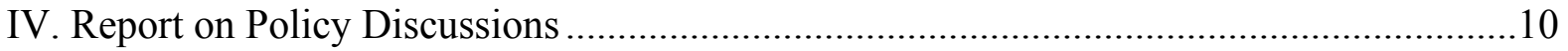

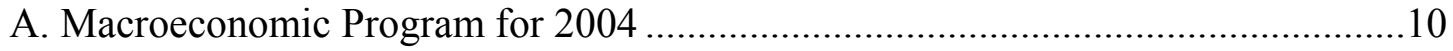

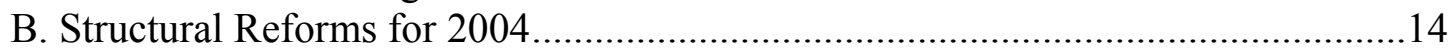

C. Medium-Term Prospects ........................................................................... 17

V. Debt Service Capacity and Relations with Creditors................................................18

VI. Program Duration and Monitoring ......................................................................... 19

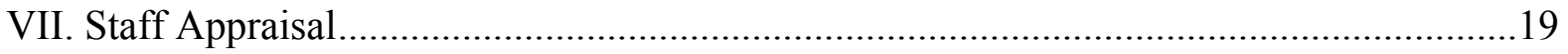

Tables

1. Quantitative Indicative Targets, 2003 ....................................................................22

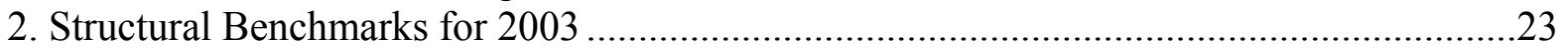

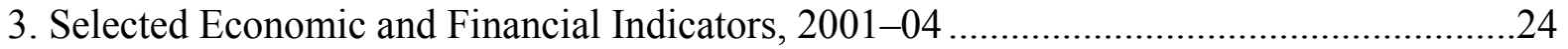

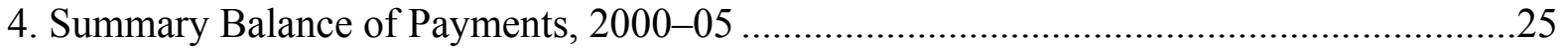

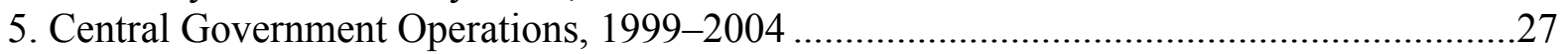

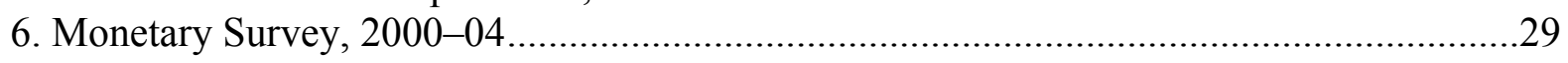

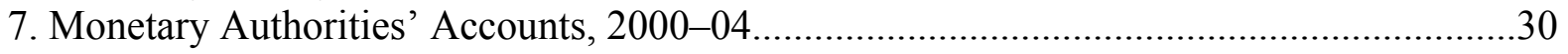

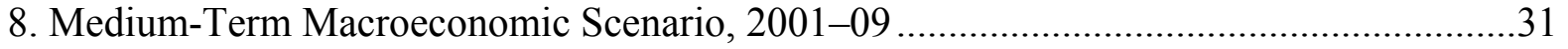

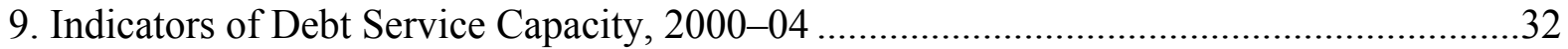

10. External Financing Requirements and Sources, 2001-04 ….......................................33

Figures

1. GDP, Prices, External, and Fiscal Developments, 2000-05 …...................................34

2. Exchange Rate Indices and International Reserves, January 2001-March 2004 ...............35

3. Monetary Developments, January 2002-March 2004 .................................................36

Boxes

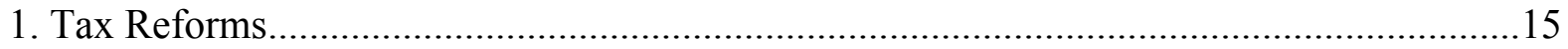

2. Public Expenditure Management Reforms ............................................................ 16 
Appendices

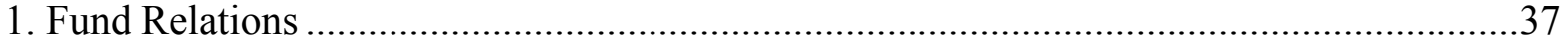

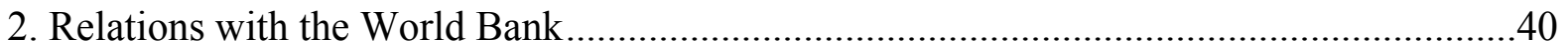

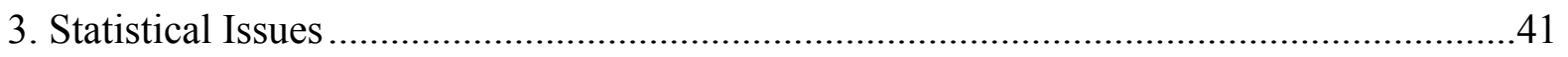

4. Strengthening External Debt Management......................................................................4

Attachments

1. Letter of Intent and Memorandum of Economic and Financial Policies...

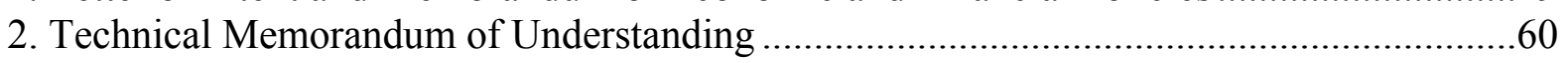




\section{List of Acronyms}

\begin{tabular}{|c|c|}
\hline AfDB & African Development Bank \\
\hline ASYCUDA & Automated System for Customs Data \\
\hline $\mathrm{BOS}$ & Bank of Sudan \\
\hline CBS & Central Bureau of Statistics \\
\hline $\mathrm{CMC}$ & Central Bank Musharaka Certificates \\
\hline CMU & Cash Management Unit \\
\hline CNPC & China National Petroleum Corporation \\
\hline CRN & Country Reengagement Note \\
\hline DFID & Department for International Development \\
\hline EDU & External Debt Unit \\
\hline FDI & Foreign Direct Investment \\
\hline FSAP & Financial Sector Assessment Program \\
\hline GDDS & General Data Dissemination System \\
\hline GFC & Government Finance Certificates \\
\hline GFS & Government Finance Statistics \\
\hline GIC & Government Investment Certificate \\
\hline GMC & Government Musharaka Certificates \\
\hline HIPC & Heavily Indebted Poor Countries \\
\hline I-PRSP & Interim Poverty Reduction Strategy Paper \\
\hline IEA & Investment Encouragement Act \\
\hline JAM & Joint Assessment Mission \\
\hline MEFP & Memorandum of Economic and Financial Policies \\
\hline MEM & Ministry of Energy and Mining \\
\hline MOD & Monetary Operations Division \\
\hline MOFNE & Ministry of Finance and National Economy \\
\hline MOU & Monetary Operations Unit \\
\hline MPC & Monetary Policy Committee \\
\hline NDA & Net Domestic Assets \\
\hline NRF & National Revenue Fund \\
\hline OIN & Other Items Net \\
\hline OPEC & Organization of the Petroleum Exporting Countries \\
\hline OSA & Oil Savings Account \\
\hline PEM & Public Expenditure Management \\
\hline PRSP & Poverty Reduction Strategy Paper \\
\hline RAP & Rights Accumulation Program \\
\hline SMP & Staff-Monitored Program \\
\hline SPC & Sudan Petroleum Corporation \\
\hline SPLA & Sudan People's Liberation Army \\
\hline SPLM & Sudan People's Liberation Movement \\
\hline TA & Technical Assistance \\
\hline UNICEF & United Nations Children's Fund \\
\hline UNCTAD & United Nations Conference on Trade and Development \\
\hline VAT & Value-Added Tax \\
\hline
\end{tabular}




\section{EXECUTIVE SUMMARY}

\section{Performance under the 2003 Staff-Monitored Program (SMP) and recent developments}

Policy performance was in line with the program, all quantitative targets, except for that on contracting nonconcessional external debt, were met, and most structural benchmarks were implemented. Sudan made the agreed payment of \$27 million to the Fund.

Real GDP grew by 6 percent, and inflation declined to 7.7 percent. The fiscal outcome was better than programmed, notwithstanding emergency spending in eastern and western Sudan, because of high oil prices and strong tax performance. The external position improved reflecting higher oil and non-oil exports and large capital inflows. Broad money grew faster than programmed because of large private capital inflows and government spending.

Peace negotiations have resolved the outstanding issues and the comprehensive peace agreement is expected to be signed in the near future. The security and humanitarian situation deteriorated in western Sudan because of tribal clashes and local insurrection.

\section{Policy discussions for the 2004 SMP}

The discussions focused on the need to reinforce macroeconomic stability and to provide for post-conflict needs. Real GDP growth is projected at 6.6 percent, and inflation is targeted at 6.5 percent under the program. A prudent fiscal stance will allow monetary policy to target a decline in broad money growth, while the exchange rate will remain flexible and international reserves will rise to 2.5 months of imports. Structural reforms will focus on tax reforms, improvements in cash management and fiscal reporting, oil sector transparency, and removal of institutional rigidities in broad money targeting. Additional fiscal measures will be taken to meet immediate post-conflict needs. The authorities will raise the payments to the Fund to $\$ 30$ million.

\section{Staff appraisal}

Economic performance under the 2003 SMP was satisfactory. Fiscal policy was supportive of the program objective. Monetary policy conduct improved, but managing the large capital inflows proved challenging in the face of limited exchange rate movements. Structural reforms progressed, but extra efforts in fiscal cash management and reporting are needed.

The 2004 program aims to meet the twin challenges of reinforcing macroeconomic stability and managing post-conflict demands. The fiscal stance will remain prudent, predicated on strong tax revenue efforts. Monetary policy would be cautious and supported by a flexible exchange rate to mitigate the impact of foreign exchange inflows, consistent with the broad money and reserve accumulation targets. Structural reforms will focus on strengthening economic policy institutions. On balance, staff deem the program adequate for staff monitoring and the quality of the envisaged policies to be equivalent in strength to a rights accumulation program. 


\section{BACKGROUND}

1. On October 31, 2003, the Executive Board concluded the 2003 Article IV consultation with Sudan and the midyear review of the 2003 Staff-Monitored Program (SMP). Directors commended Sudan's performance under the 2002 and 2003 SMPs. They urged the authorities to maintain a cautious monetary policy, ensure exchange rate flexibility, strengthen tax revenues, and improve external debt management. Directors also welcomed the steps to increase the transparency of the oil sector and supported adjusting the oil savings account (OSA) rules to allow the use of additional resources to support the country's development needs. Most Directors considered the 2002 and 2003 SMPs to be of equivalent strength to a rights accumulation program (RAP) and that this should be fully reflected in the period of a RAP. A few others cautioned that it was premature to consider the treatment of the SMP under an eventual RAP, until financing assurances are in place.

2. The government and the Sudan People's Liberation Army (SPLA) signed on May 26, 2004 agreements on the outstanding issues regarding the status of the capital and three areas bordering the south and the sharing of political power at the national level. Agreements on security and resource-sharing were signed earlier in September 2003 and January 2004, respectively. In the next few weeks, the parties will consolidate all the agreements into a single peace agreement and finalize the implementation modalities. Hostilities broke out in Darfur in western Sudan in 2003 because of tribal clashes and local insurrection. A ceasefire has recently been negotiated through Chad's intermediation, but the situation remains grave.

\section{Performance Under the Program}

3. Policy performance in $\mathbf{2 0 0 3}$ was in line with the program. All quantitative targets were met with the exception of that on nonconcessional external debt (Table 1). Most structural benchmarks were implemented (Table 2), with the exception of expenditure management and fiscal reporting, in part because of capacity constraints. In addition, the audit and consolidation of the Sudan Petroleum Corporation (SPC) subsidiaries accounts have not been completed.

\section{RECENT DEVELOPMENTS}

4. Macroeconomic developments were broadly in line with projections in 2003. Real GDP growth is estimated at 6 percent in 2003, compared with the 5.8 percent estimated previously. The increase is on account of higher growth in non-oil GDP of 5.5 percent (compared with 5.2 percent estimated earlier). Oil GDP growth was strong at 13 percent. The average CPI inflation rate slowed to 7.7 percent in 2003 compared with 8.3 percent in 2002 and 7 percent under the program (Figure 1, Table 3).

5. Sudan's balance-of-payments position has strengthened in 2003. The external current account deficit (on cash basis) declined to 4.9 percent of GDP in 2003 from 6.2 percent in 2002 (Table 4), reflecting higher exports of oil, the recovery in non-oil exports and larger-than-expected private transfers. Large capital inflows, including foreign direct investment (FDI), continued to finance the current account deficit. The overall improvement 
in the balance of payments allowed for a significant buildup in useable official reserves by \$283 million to \$527 million (1.8 months of imports compared with 1.0 month in 2002), above the program target of $\$ 456$ million. Foreign exchange markets were stable in 2003, and the exchange rate vis-à-vis the U.S. dollar appreciated by 1 percent (Figure 2). ${ }^{1}$ However, the nominal and real effective exchange rates depreciated by 9.7 percent and 4.5 percent, respectively, because of the U.S. dollar depreciation against other major currencies.

6. The fiscal outcome in $\mathbf{2 0 0 3}$ was better than expected. The overall fiscal balance was in surplus at 1 percent of GDP (Table 5) compared with a balanced budget under the program ( 0.2 percent of GDP and -0.5 percent of GDP, respectively, excluding savings in the OSA). Non-oil revenues, including taxes, were in line with the program projection, while

Sudan: Government Operations, 2002 and 2003

(In percent of GDP)

\begin{tabular}{lrrr}
\hline & Actual & Program & $\frac{\text { Actual }}{2003}$ \\
\hline Revenue & 2002 & 13.5 & 16.8 \\
Oil 1/ & 12.1 & 5.5 & 8.8 \\
Non-oil & 4.7 & 8.1 & 8.0 \\
Expenditures & 7.4 & 13.5 & 15.8 \\
Current & 13.0 & 10.7 & 12.7 \\
Capital 2/ & 9.9 & 2.8 & 3.1 \\
Overall balance & 3.1 & 0.0 & 1.0 \\
Balance (excluding OSA) & -0.8 & -0.5 & 0.2 \\
Non-oil domestic balance & -1.1 & -4.9 & -7.3 \\
\hline
\end{tabular}

Sources: Sudanese authorities; and Fund staff estimates.

1/ Crude oil only.

2/ Repayments for oil projects hitherto classified as capital participation in refinery have been reclassified as principal payments.

higher-than-expected oil prices, production, and government share in oil production, drove oil revenue above program projections. ${ }^{2}$ Total expenditures exceeded the target by

\footnotetext{
${ }^{1}$ The exchange rate has been managed tightly to prevent faster exchange rate appreciation in response to the rapid increase in capital inflow in 2003.

${ }^{2}$ Government share of oil production rose for two reasons: higher international oil prices and an unanticipated increase resulting from the switch to cash payment for the pipeline fees (as the previous in-kind payments were determined using oil prices at significant discount from international prices). Between 2002 and 2004, the nonoil domestic budget deficit is projected to rise because spending was increased in line with a permanent increase in oil production (the revenue associated with high oil prices was to a large extent saved in the OSA). Oil
} 
2.3 percent of GDP, reflecting mainly the emergency spending on both the floods in eastern Sudan and the humanitarian relief and security in western Sudan during the second half of the year. As a result, the non-oil domestic budget deficit rose to 7.3 percent of GDP, 2 percentage points of GDP higher than in 2002. The OSA balance rose by SDD 36 billion ( 0.8 percent of GDP) to SDD 45.2 billion (1 percent of GDP) by end-December 2003 (Table 5).

7. Monetary growth accelerated in the second half of 2003, mostly because of a sharp increase in private capital inflows and higher government spending. However, in the last two months of 2003, the BOS took steps to mop up liquidity, and broad money growth was limited to 30.3 percent (on annual basis) at end-December, compared with a program target of 23 percent. ${ }^{3}$ Measures implemented included reducing lending to the government, open market sales of government securities, and recalling BOS loans to banks. Reserve money grew by 27 percent (on annual basis) at end-December, compared with 22 percent at end-2002, reflecting a substantial increase in net foreign assets of the BOS. The flexibility of monetary policy to sterilize the foreign exchange inflows was reduced by the tightly managed exchange rate. This prevented faster appreciation of the exchange rate that could have helped further slowing down broad money growth.

Monetary Developments, December 2002-December 2003

(In billions of Sudanese dinars)

\begin{tabular}{|c|c|c|c|c|}
\hline & Dec. 2002 & $\frac{\text { Program }}{\text { Dec. } 2003}$ & Dec. 2003 & $\begin{array}{r}\text { Percent } \\
\text { Change } \\
\text { (from } \\
\text { end-2002) }\end{array}$ \\
\hline Reserve money & 280.3 & 335.4 & 354.8 & 26.6 \\
\hline $\begin{array}{l}\text { NFA (excluding valuation } \\
\text { adjustment) }\end{array}$ & 169.9 & 233.8 & 247.1 & 45.5 \\
\hline NDA & 393.4 & 460.5 & 487.0 & 23.8 \\
\hline $\begin{array}{l}\text { Broad money } \\
\text { Of which }\end{array}$ & 563.3 & 694.3 & 734.1 & 30.3 \\
\hline Credit to government & 130.8 & 101.4 & 111.7 & -14.6 \\
\hline $\begin{array}{c}\text { Credit to } \\
\text { nongovernment }\end{array}$ & 198.9 & 285.7 & 312.1 & 56.9 \\
\hline
\end{tabular}

Sources: Sudanese authorities; and Fund staff estimates.

8. There was progress in key structural fiscal reforms in 2003, though cash management and fiscal reporting still need attention. In the fiscal area, the authorities launched a program to reform the direct tax system and established a large taxpayer unit.

production rose from $232,000 \mathrm{bpd}$ to $300,000 \mathrm{bpd}$. The government's oil share, however, rose by a faster rate from $120,000 \mathrm{bpd}$ to $213,000 \mathrm{bpd}$, reflecting, in part, maturing contracts.

${ }^{3}$ Without these measures, broad money growth was projected to reach about 35 percent by end 2003. 
Reforms of the tax incentive regime of the Investment Encouragement Act (IEA), including tightening exemption criteria, centralizing the authority to grant exemptions, and setting limits on renewing exemptions, were implemented. The authorities also made progress in developing a medium-term fiscal framework in the context of the 2004 budget. However, there was limited progress in improving cash management and fiscal reporting, partly owing to capacity constraints.

9. Reforms to further improve the transparency of the oil sector have been slow. While an annual audit of the SPC was conducted, audits of its subsidiaries as well as the consolidation of their accounts in the parent company's budget still remain to be done.

10. All structural reform measures in the monetary area were undertaken. A monetary operations unit (MOU) was established at the BOS, a new government securitythe Government Investment Certificates (GICs) ${ }^{4}$ - was launched, and the central bank law was amended by parliament to, among other things, establish central bank independence and strengthen banking regulations. In addition, an anti-money laundering law was enacted, and a study examining the possibility of introducing market-based agricultural finance hedging instruments was completed. ${ }^{5}$

11. The banking system's prudential performance has improved. The capital adequacy ratio for the banking system as a whole reached 9.9 percent at end-December 2003, and 17 banks (of a total of 24 banks) complied with capital adequacy requirements. The asset quality of banks improved in 2003; the ratio of nonperforming loans to total loans declined to 11.4 percent, and the ratio of loan provisions to nonperforming loans declined to 22 percent. As of December 2003, BOS's measurement of banking system compliance with prudential standards shows that the performance of 14 banks was rated as fair or better. ${ }^{6}$

Bank Soundness Indicators (end-year)

\begin{tabular}{lrrrr}
\multicolumn{4}{c}{ (In percent) } & \\
& 2000 & 2001 & 2002 & 2003 \\
\hline Capital adequacy ratio & 7.0 & 11.0 & 9.0 & 9.9 \\
Ratio of nonperforming to total loans & 17.0 & 16.0 & 12.7 & 11.4 \\
Ratio of loan provisions to bad loans & 29.0 & 23.0 & 24.0 & 22.0 \\
\hline
\end{tabular}

Sources: Sudanese authorities; and Fund staff estimates.

\footnotetext{
${ }^{4}$ The GIC is a second-generation government security that complies with Islamic finance principles. In contrast to the earlier instruments, the GIC pays investors a stable income and can be structured for long-term maturities.

${ }^{5}$ The study was conducted with Fund technical assistance and concluded that the establishment of a futures market for agricultural product is not viable for Sudan at present, and instead recommended establishing a structured forward commodities market.

${ }^{6}$ The BOS has established a system to track banks' prudential performance and has been penalizing banks that fail to meet the BOS capital augmentation schedule, including through withholding dividend distributions.
} 
12. The privatization program proceeded at a reasonable pace in 2003. Gross privatization proceeds are estimated at SDD 9.9 billion in 2003 ( $\$ 38$ million) compared with a projected SDD 6 billion (\$23 million). These proceeds were mainly from Duty-Free Shops and Free Zone, the Sudanese Estate Bank, and Atbara Cement Factory. The Sudanese Estate Bank and Atbara Cement Factory are both now 100 percent foreign-owned. The privatization of Khartoum Bank has advanced, albeit at a slower pace than expected with 20 percent of its shares privatized thus far.

13. During the first quarter of 2004, the exchange rate vis-à-vis the U.S. dollar appreciated by 0.3 percent, and inflation rose to 9.2 percent (year-on-year) by end-March. Fiscal revenues (oil and non-oil) performed better than expected, and the budget was almost balanced. Broad money growth, however, continued to accelerate, reaching 36 percent (yearon-year) by end-March, which was fueled largely by foreign exchange inflows. Sudan has contracted a credit line from the EXIM bank of India for $\$ 50$ million and a supplier credit line from China for $\$ 95.8$ million. $^{7}$

\section{Report on Policy Discussions}

\section{A. Macroeconomic Program for 2004}

14. The $\mathbf{2 0 0 4}$ program aims to reinforce macroeconomic stability and sustain economic growth, while providing for post-conflict needs. Real GDP is expected to grow by 6.6 percent, reflecting higher growth in both oil and non-oil sectors - the former is expected to grow by 14.4 percent and the latter by 5.8 percent, spurred by construction, services, and power sector growth (Table 3). CPI inflation is targeted to fall to 6.5 percent in 2004. A prudent fiscal stance will keep the domestic financing of the deficit low, and monetary policy will target lower broad money growth in 2003 while keeping the exchange rate flexible. The structural reform agenda aims to build on recent progress in strengthening economic policy institutions. Additional fiscal measures are also envisaged to meet the immediate post-conflict needs if a peace agreement is reached in 2004.

\section{The external current account deficit (on a cash basis) will slightly increase} in 2004, reflecting mainly investment-related additional imports. Overall exports are projected to increase by 16.5 percent on account of higher prices, and import volumes are expected to grow faster in large part owing to the Merowe hydropower project. The current account deficit will continue to be financed by private capital inflows (mostly FDI) and, to a

\footnotetext{
${ }^{7}$ The Indian credit line has a grant element of 16 percent and will be used to finance infrastructure projects, including in rural areas. The Chinese credit line has a grant element of 13 percent and will be used for water projects that will be implemented over a number of years. In addition, a memorandum of understanding has been signed between a number of Sudanese public enterprises and Chinese counterparts for financing additional infrastructure projects (mostly energy and railway) in the amount of about $\$ 150$ million. A decision has not yet been made on contracting these loans and whether the government will guarantee them.
} 
lesser extent, by project loan disbursements. Official reserves are targeted to rise by $\$ 280$ million to $\$ 807$ million, equivalent to 2.5 months of next year's imports, compared with 1.8 months at end-2003 (Table 4).

\section{Fiscal Policy}

16. The fiscal stance will remain prudent. The overall fiscal deficit is expected to be about 1.2 percent of GDP (2.3 percent of GDP excluding OSA), largely on account of foreign-financed development expenditures on the Merowe dam, ${ }^{8}$ while the non-oil domestic deficit is projected to rise by 1.5 percentage points to 8.8 percent of GDP in 2004 (Table 5). The domestically financed fiscal deficit (excluding the OSA) will be contained at about 1.0 percent of GDP, consistent with a restrained monetary program.

\section{Overall revenues are expected to increase in 2004 from both non-oil and oil} sources (Table 5). Non-oil revenues are estimated to rise by 1 percentage point of GDP to close to 9 percent in 2004, reflecting the adoption of a set of new revenue measures that were approved in the 2004 budget (MEFP, $\mid 12) .{ }^{9}$ Oil revenue will also increase by 1 percentage point of GDP, reaching 9.8 percent in 2004, on account of higher price and production of Sudanese oil. ${ }^{10}$

18. The benchmark price, above which oil revenues accumulate in the OSA, will be raised slightly in light of the higher international oil price. Consistent with the need for more flexible OSA rules to balance the fiscal security provided by the OSA with poverty alleviation and development needs, the mission agreed with the authorities on the appropriateness of raising the OSA benchmark price by $\$ 2$ per barrel to $\$ 24$ in light of the projected high oil prices. The extra revenues will be spent on additional social and development programs (MEFP, $\mid 21$ ). Despite the benchmark price increase, the OSA is expected to accumulate an additional SDD 55.5 billion (1.1 percent of GDP) in $2004 .{ }^{11}$ The OSA benchmark price will be kept under review during the year and adjusted, if necessary, in light of unexpected movements in oil prices.

\footnotetext{
${ }^{8}$ The 2004 budget will record a surplus of about 1 percent of GDP excluding foreign-financed development spending.

${ }^{9}$ To support the post conflict needs, the authorities identified a number of revenue measures that will be enacted once a peace agreement is reached (MEFP, $\mid 13)$. The revenues resulting from these measures were not included in the program projections, but could generate about 0.2 percent of GDP in the second half of 2004.

${ }^{10}$ The program assumes an average annual price of Sudanese oil of $\$ 28.2$ per barrel.

${ }^{11}$ The OSA's projected balance by end-2004 should be sufficient to finance 12-month spending levels similar to those in 2004 in case Sudanese crude oil price drops to \$20 per barrel from the program's assumption of $\$ 28.2$ per barrel.
} 
19. Both current and capital spending are expected to rise significantly in 2004. Current expenditures are expected to increase from 12.7 percent of GDP in 2003 to 14.3 percent in 2004 (Table 5), reflecting three factors. First, public sector wages and pensions were budgeted to rise by 50 percent as a result of a significant increase in the minimum wage, a structural wage adjustment, and an increase in pension payments. ${ }^{12}$ The authorities viewed this increase, particularly that on the minimum wages, as part of their efforts to alleviate poverty and to correct the recent lagging of public wages behind those in the private sector, which had resulted in recruitment problems. The mission advised that the proposed increase would reduce budget flexibility and divert resources away from targeted poverty reduction and peace-related programs. The authorities agreed to moderate the increase to 38 percent. Second, transfers to the states are budgeted to increase by 0.8 percent of GDP, reflecting mostly additional peace-related expenditures. Third, additional resources are allocated under general reserves for the humanitarian and security operations in Darfur. Military spending is budgeted to remain unchanged compared with 2003 at about 2.5 percent of GDP, and spending on social programs (including health, education, and water) will increase to 1.7 percent of GDP compared with 1.2 percent of GDP in 2003. Development spending is projected to increase by 2.5 percentage points of GDP to 5.6 percent, largely because of the foreign-financed Merowe dam project (1.7 percent of GDP). ${ }^{13}$

\section{Monetary and exchange rate policy}

20. The monetary policy needs to be cautious in light of uncertainties related to foreign exchange inflows, the impact of peace, and potential shifts in money demand. Monetary policy will target a broad money growth of 22 percent in 2004 (Table 6), consistent with the growth and inflation objectives, and some decline in velocity. The monetary target will be reassessed at the midyear review to ensure consistency with the program's macroeconomic objectives. The authorities indicated their commitment to tighten monetary policy, if necessary, to meet the program objectives.

\section{The mission welcomed the authorities' commitment to reining in the rapid} monetary expansion, but stressed that absorbing excess liquidity and managing foreign exchange inflows will be a challenge. Efforts will be intensified in the first half of 2004 to absorb liquidity through open market operations and reduced BOS lending to banks, to bring monetary aggregates back in line with the program targets (MEFP, $\mid 22$ ). ${ }^{14}$ The mission noted, however, that supportive exchange rate policy would be needed to achieve the monetary target in the face of continued strong foreign exchange inflows.

\footnotetext{
${ }^{12}$ The minimum wage was raised from SDD 7,500 per month (\$28) to SDD 12,500 per month (\$48).

${ }^{13}$ Total expenditures, excluding foreign-financed capital spending, are projected to rise between 2002 and 2004 by 4.9 percent of GDP, funded by an increase in non-oil revenue of 1.5 percent of GDP and a substantial increase in oil production.

${ }^{14}$ In addition, the BOS will no longer extend credit to agriculture.
} 
22. The authorities are committed to a managed-float exchange rate regime and will take measures to increase exchange rate flexibility (MEFP, I25). The mission noted that the exchange rate has been tightly managed so far, which has reduced the effectiveness of monetary policy. Accordingly, the authorities agreed to widen the BOS's intra-day exchange rate fluctuation margin gradually in 2004 from the current \pm 2 percent over the previous day average market rate to \pm 3 percent. However, the authorities noted their concern that strong exchange rate movements could destabilize the foreign exchange market. ${ }^{15}$ The authorities also intend to maintain a foreign exchange system free from restrictions on current account transactions in accordance with their acceptance of the obligations under Article VIII, Sections 2, 3, and 4 of the Fund's Articles of Agreement. ${ }^{16}$

\section{Trade regime}

23. While the authorities recognize the need for further trade liberalization, they are concerned about the revenue losses associated with further lowering of tariff protection and the substantial resource requirement for peace and poverty reduction programs (MEFP, ๆ26). A medium-term tariff reform program in the context of the 2005 budget will aim to further reduce tariff protection. ${ }^{17}$ The program, however, will be coordinated with efforts under way to strengthen taxation to compensate the revenue losses from the tariff reform. The authorities reaffirmed their commitment to an open trade regime with respect to nontariff barriers. Sudan has progressed well in the WTO accession process, as acknowledged in the Second Working Party Meeting in March 2004, and plans to submit to the WTO the two final documents, necessary for accession, by mid-2004.

\section{External debt management}

24. The authorities plan to address the external debt management challenges of the post-peace period (MEFP, $\mid 28$ ). They will formulate and implement a new external borrowing policy, consistent with Sudan's repayment capacity and long-term debt sustainability. A high-level Debt Policy and Monitoring Committee, comprising senior ministry of finance and national economy (MOFNE) and BOS officials will be established in the second quarter of 2004 to formulate and implement external debt and new borrowing policies by September 2004. A three-year rolling ceiling on external borrowing will be

\footnotetext{
${ }^{15}$ The foreign exchange market in Sudan is relatively thin and lacks appropriate hedging instruments (e.g., forward exchange rate market).

${ }^{16}$ The staff is conducting a review of Sudan's foreign exchange regulations to ensure that the exchange rate regime is compliant with the requirements of Article IV, Sections 2, 3, and 4, of the Fund's Articles of Agreements.

${ }^{17}$ The simple average tariff is 22.6 percent, and currently, there are four nonzero tariff rates: $3,10,25$, and 45 percent. However, sugar imports are subject to a stabilization tax in addition to the regular import duty of 45 percent. Sudan's trade regime is relatively open and would most likely rank at about the industrial countries' average under the Fund's Trade Restrictiveness Index.
} 
incorporated in the 2005 budget. The mission urged the authorities to improve capacity for post-peace negotiation and implementation of Heavily Indebted Poor Countries (HIPC)related debt rescheduling and relief agreements (see Appendix IV for a summary of staff assessment and recommendations). With respect to the newly contracted external debt, the authorities explained that these were necessary to finance vital development projects (e.g., water supply), and because of the external debt overhang, they could not secure financing on concessional terms. They indicated that they will not contract or guarantee new external debt on nonconcessional terms, hoping that the upcoming peace will give Sudan access to concessional financing. While acknowledging the development needs of Sudan, the mission pointed out that continued borrowing on nonconcessional terms could potentially worsen Sudan's external debt overhang situation.

\section{Preparing for peace}

\section{The authorities have prepared an amended budget that will be presented to} parliament upon completion of the peace agreement. The amended budget will consider measures to mobilize additional resources of about 1 percent of GDP in the second half of the year to cover the immediate post-conflict needs through revenue measures and spending reallocations. If some of the envisaged revenue measures are not approved, expenditures would be reduced further across most budget sectors to cover the gap, while protecting social and key development programs of the original budget (MEFP, $₫ 14$ ). The authorities, however, stressed that the post-conflict needs will be very large and, while they will mobilize as much domestic resources as possible, a substantial financing gap would emerge. They expressed their hope that the international community will provide adequate assistance in a timely manner to close the financing gap.

\section{B. Structural Reforms for 2004}

\section{Revenue reforms would stress the removal of exemptions and the strengthening} of tax and customs administration, in line with recommendations of the Fiscal Affairs Department (FAD). Following approval of the 2004 budget, the authorities have begun implementing a number of revenue measures, expected to amount to about 0.9 percent of GDP (see Box 1). Further, in response to the mission's observation that non-IEA exemptions, often granted on an ad hoc basis, have been resulting in significant revenue losses, the authorities agreed to a complete ban, through a Cabinet decision, on the granting of ad hoc exemptions and to initiate a program review and reform exemption-granting regulations and laws outside the IEA (MEFP, ๆ6). Tax and customs administration reform will focus, inter alia, on making the Large Taxpayer Unit fully operational and broadening the definition of large taxpayers to include individuals. 


\section{Box 1. Tax Reforms}

As part of the ongoing fiscal reforms, the authorities are implementing a number of measures during 2004. These can be divided into two broad categories-reforms to strengthen revenues and streamline exemptions and efforts to strengthen tax administration.

\section{Revenues and tax exemptions}

- eliminating the 10 percent privilege tax rate on the income of professionals;

- imposing an excise tax on petroleum products;

- raising the excise tax rate on sugar;

- raising the selling price of crude oil to refineries;

- introducing steps to enforce departmental fee collection;

- abolishing corporate tax exemptions for rehabilitation purposes;

- eliminating the non-oil related tax privileges of the four major oil distribution companies; and

- banning, through a cabinet decision, all exemptions granted outside the IEA.

\section{Tax administration}

- making the recently established Large Taxpayer Unit fully operational by mid-2004. The unit is expected to cover about 200 of the largest tax-paying entities, accounting for about 60 percent of business and profit taxes and 70 percent of value-added tax (VAT) collections;

- broadening the definition of large taxpayers beyond corporations to include individuals;

- introducing a taxpayer identification number that would apply to all taxes, including for excise duties;

- beginning to transfer VAT collected by customs to the tax directorate on a daily basis;

- launching a pilot project in audit enforcement to increase field audits; and

- $\quad$ applying, nationwide, the Automated System for Customs Data (ASYCUDA)++, a selective risk-based verification system.

\section{Greater effort would be devoted to improve oil sector transparency.}

Notwithstanding the progress in improving transparency, including the completion of an audit of the SPC, staff underscored the need for more wide-ranging efforts. The authorities agreed and have subsequently prepared a timetable of 2004 actions that includes audits of SPC subsidiaries and the launching of a program to align their accounts with international standards.

28. Public expenditure management and fiscal reporting will be strengthened, and the budget classification system will be improved (see Box 2). To address budget control and monitoring deficiencies, which often result in unanticipated spending cuts without consideration of priorities, the authorities plan to fully activate a cash management unit by mid-2004 with Fund technical assistance. They have begun to improve fiscal reporting and have agreed to a move to a functional and economic budget classification under the 
government finance statistics (GFS) (MEFP, ๆ19) to allow for uniform budgeting and accounting systems at the central and state government levels and better target social and poverty reduction programs.

\section{Box 2. Public Expenditure Management Reforms}

The January 2004 Wealth-Sharing Agreement between the government and the Sudan People's Liberation Movement (SPLM) provides the basis for a broader framework for public expenditure management (PEM) reform in Sudan. The Agreement contains the following provisions with respect to PEM:

- all revenue collected nationally for or by the national government is to be pooled in a National Revenue Fund (NRF) that is administered by the national treasury;

- the NRF is to embrace all accounts and subfunds into which monies due to the government are collected, reported, and deposited; and

- $\quad$ all government revenues and expenditures are to be on-budget and made public.

These provisions constitute parts of an appropriate strategic framework for developing the PEM system in Sudan. They address the current problems of extra-budgetary operations and a lack of fiscal transparency and could become a basis for the establishment of a modern treasury, including a single treasury account.

Within this strategic framework, the authorities have committed to implement immediate measures in three areas: cash management, fiscal reporting, and budget classification. To this end, they will:

- $\quad$ establish a cash management unit; appoint a cash release committee; issue the relevant regulations in line with Fund recommendations; and make the unit fully operational by mid-2004;

- develop an action plan to strengthen fiscal reporting and begin preparing monthly fiscal reports within two weeks after the end of each month by improving overall coordination in preparing monthly accounts, further computerization of the government accounting system, and training of budget accountants.

- $\quad$ adopt a two-year program to align the budget classification with the Government Finance Statistics Manual, 2001, including the following stages: (i) classifying at the federal level, the current sectors into the GFS functions by end-June 2004; (ii) incorporating in the 2005 budget presentation, a functional classification of expenditure in addition to the traditional presentation by sectors; (iii) implementing the 2005 budget in some pilot ministries along the old and the new classification lines; and (iv) adopting the GFS classification fully with the 2006 budget.

The authorities will need further technical assistance to implement these measures, and FAD plans such technical assistance missions in the course of 2004.

29. Operations at the BOS would be streamlined to overcome institutional rigidities in implementing the broad money-targeting regime. The authorities intend to transform the existing MOU at the BOS into a monetary operations division (MEFP, $\mid 23$ ), enabling it to efficiently coordinate open market operations in securities and foreign exchange, and banks' access to standing credit facilities. 
30. Banking system reforms are needed. While acknowledging progress, thus far, the mission stressed the need to develop a medium-term reform plan based on a comprehensive assessment of the present condition of the banking system. The authorities reiterated their request for a financial sector assessment program (FSAP), which could form the basis of the reform plan. ${ }^{18}$

31. The authorities plan to continue with their ongoing program of privatization. Building on the aggressive privatization drive launched in 2002, the authorities plan to privatize a number of state-owned entities in 2004. ${ }^{19}$ These efforts are expected to yield a more than 50 percent increase in gross receipts to about $\$ 60$ million in 2004.

\section{Work on the Poverty Reduction Strategy Paper (PRSP) is expected to progress} further, especially once peace is reached. The authorities have made progress on the Interim Poverty Reduction Strategy Paper (I-PRSP) (with help from the World Bank), though the development of, and consultation for, a full poverty reduction strategy would require countrywide participation after peace is reached.

\section{Medium-Term Prospects}

33. Underpinned by sound macroeconomic policies, Sudan's medium-term strategy should be able to yield sizable growth, low inflation, and poverty reduction over the medium term. ${ }^{20}$ Real GDP is expected to grow at 7 percent, reflecting higher expected oil production as well as continued non-oil growth - mainly in construction, power, and services (Table 8). Inflation will remain low, ranging at about 5 to 6 percent, largely owing to the restrained monetary policy supporting a low domestically-financed fiscal deficit. While the share of agriculture in GDP is expected to continue to fall, manufacturing is expected to grow steadily (at about 5 percent), contributing to poverty reduction over the medium term.

\section{The authorities envisage the benefits of international engagement after peace} will outweigh the peace-related costs. With the continuation of sound macroeconomic policies and arrears clearance following peace, the improvement in relations with the international community is expected to relax the external financing constraint (including through FDI). The higher available financing, in conjunction with greater oil production, will allow Sudan to finance its heavy investment needs. The authorities, however, are concerned that delays in resolving the external debt arrears problem would hinder Sudan's ability to access concessional external finance and undermine the post-conflict reconstruction and

\footnotetext{
${ }^{18}$ An FSAP mission is scheduled to take place in mid-2004.

${ }^{19}$ The companies to be privatized in 2004 include the Bank of Khartoum, Sudanese Telecommunication Company, and Rabak Cement Factory.

${ }^{20}$ The medium-term outlook reflects, at this stage, a cautious view on the impact of peace, given the uncertainties about the final outcome of the peace negotiations and the extent of external assistance to Sudan for development and debt relief. Accordingly, the medium-term outlook should be viewed as work in progress.
} 
development programs, which in turn would undercut economic growth and limit the effectiveness of the envisaged poverty reduction programs.

\section{Debt Service Capacity and Relations With Creditors}

35. Sudan's debt service capacity remains low and fragile. An improved external position is expected to increase external debt service capacity by $\$ 50$ million in 2004 (to about \$297 million). Despite this, the overall debt service ratios will barely improve - the debt service/net current receipts ${ }^{21}$ ratio is projected to decline slightly from 15.6 percent in 2003 to 14.8 percent in 2004 (Table 9). While greater external financing is expected to offset the increased debt service (Table 10), a sizable external financing gap could easily open if international oil prices or private inflows were to drop. A buildup of international reserves would likely be inadequate in the face of a large oil price shock, forcing import compression and making it more difficult to meet debt service payments.

\section{Sudan plans to continue to improve its relations with non-Fund creditors.}

In 2003, Sudan resumed debt service payments to the World Bank ( $\$ 5.5$ million) and the African Development Bank (AfDB) (\$3 million), and in 2004, the authorities will continue payments to these institutions as well as to the Islamic Development Bank, International Fund for Agricultural Development, Arab Fund for Economic and Social Development, Organization of the Petroleum Exporting Countries (OPEC) Fund for International Development, Arab Monetary Fund, and a number of bilateral Arab funds. The resumption of payments to these institutions will result in net financing reflows. ${ }^{22}$ The largest payments in 2004 would be made to China ( $\$ 102$ million) mainly to service Khartoum oil refinery construction loans. $^{23}$

37. Based on projected debt service payment capacity, Sudan's payment to the Fund could be increased slightly in 2004 . The authorities proposed to increase the payment to the Fund to $\$ 30$ million compared with about $\$ 12$ million required to stabilize Sudan's arrears to the Fund. This modest increase will be in line with the overall increase in the debt service and will keep the ratio of payment to the Fund to the payment capacity indicator, measured in terms of net current receipts, at about the 2003 levels (Table 9). The authorities expressed their hope that the payment to the Fund will be reviewed after a peace agreement is reached to take into account the post-conflict financing needs of Sudan.

\footnotetext{
${ }^{21}$ Net current receipts are defined as current receipts net of oil-related payments to foreign investors and net of international reserve accumulation.

${ }^{22}$ Total debt service payments to these creditors (excluding the World Bank and AfDB) are projected to be $\$ 82$ million, while new disbursements from them will be over $\$ 300$ million.

${ }^{23}$ The Khartoum refinery, a joint venture between Sudan and the China National Petroleum Corporation (CNPC) (with mostly Chinese financing), supplies the bulk of petroleum products consumed in Sudan. If debt service for it is not met, the CNPC has the right to lift the equivalent of crude oil in kind; thus, nonpayment is not a realistic option.
} 


\section{Program Duration AND Monitoring}

38. The program period will be one year, ending on December 31, 2004. The staff proposes to maintain the present cycle of semi-annual Board reviews for end-June and endDecember performance. However, the staff would continue to conduct quarterly review missions and report any significant developments or deviations from the program to the Board during informal country matters sessions.

\section{StAFF APPRAisAL}

39. Sudan has made substantial progress under successive SMPs since 1997 in achieving macroeconomic stability and advancing structural reforms. In 2002 and 2003, Sudan implemented strengthened SMPs with economic policies equivalent to what would have been required under a RAP. These programs aimed at bolstering macroeconomic stability, reinforcing the reform momentum, and strengthening economic policy institutions. Significant progress has been achieved on all fronts, resulting in substantial dividends in terms of strong economic growth and a surge in foreign investment.

40. Sudan faces a twin challenge to economic policy in 2004: reinforcing macroeconomic stability and managing the post-conflict demands. At the policy level, this would require a fiscal stance that maintains a low domestically financed deficit, mobilizes additional resources, and directs expenditures to meet the obligations of peace. Monetary policy should be cautious and the exchange rate flexible to mitigate the impact of the foreign exchange inflows (which are likely to accelerate after peace), consistent with the targets on broad money growth and international reserve accumulation.

41. The authorities' focus on pursuing prudent fiscal policy and raising non-oil revenue is welcome. Strengthening tax revenue remains an important fiscal reform objective to limit reliance on oil revenue and raise much-needed fiscal resources. In particular, further reduction in tax exemptions is important to mobilize additional revenue and promote fiscal transparency and a more equitable tax regime. In addition, the authorities' intention to contain military spending while increasing spending on social development and agriculture support programs is appropriate. The sizable increase in the wage bill, however, is a cause for concern. This increase has reduced fiscal flexibility and may have limited the resources that could have been allocated to social and poverty alleviation programs. The staff urges the authorities to moderate future wage increases and to phase them over a longer period of time.

42. The authorities' fiscal effort to prepare for peace is commendable. The contingency fiscal measures that are envisaged once a peace agreement is signed should provide additional resources for the immediate post-conflict needs. Further efforts are needed to mobilize more revenues over the medium term and realign expenditures to support the postconflict reconstruction and development needs. Sudan, however, will not be able to finance all the post-conflict needs from domestic resources, and international donor support will be needed. 
43. The OSA mechanism has been an important tool in restraining government spending over the past two years in the face of a rapid rise in oil revenue, while building up international reserves and preventing further monetary expansion. The authorities' commitment to maintain the OSA is welcome, and the envisaged flexibility in determining the speed of OSA reserve accumulation, through frequent reviews, is appropriate to provide a balance between Sudan's economic development needs and the fiscal security provided by the OSA.

44. Strong actions are needed to reduce broad money growth to the program target by limiting high-power monetary emission from the BOS and absorbing bank liquidity through open-market operations. The effectiveness of these efforts would need a supportive flexible exchange rate policy. Coordinating the monetary policy actions will be challenging, and the staff urges the authorities to activate the envisaged monetary operations division at the BOS.

45. Sudan's contracting in recent months of a few loans on nonconcessional terms is a cause of concern. Notwithstanding Sudan's lack of access to development concessional finance because of its external debt arrears, it is important to curtail nonconcessional borrowing to prevent aggravating the external debt overhang and complicating the eventual HIPC debt relief process. The authorities' commitment to strengthen external debt management is welcome. In particular, establishing the external debt monitoring committee and formulating an external debt policy are important steps to control public sector borrowing and ultimately facilitate the resolution of Sudan's external debt overhang.

46. The staff welcomes the authorities' commitment to maintain a relatively open trade regime and develop a new medium-term tariff reform plan in the context of the 2005 budget. While Sudan's economy has benefited from opening its trade regime, the staff recognizes the importance of phasing further tariff liberalization with compensatory revenue measures to secure the resources needed to finance development, reconstruction, and poverty reduction programs after peace, and to ensure that the fiscal policy stance is not weakened in the medium term.

47. The authorities are urged to take the necessary steps to ensure the consolidation of the accounts of all oil sector operations according to best international standards. These measures are important commitments under the program to reinforce oil sector transparency.

48. The 2004 program faces a number of risks. Delays on the peace front might increase economic uncertainty and undermine private capital inflows, which in turn would create balance-of-payments difficulties. On the other hand, a peace agreement and its associated spending commitments in the near future may result in fiscal pressures if donor support does not materialize in a timely manner and foreign exchange inflows (FDIs and private transfers) surge; both could undermine macroeconomic stability. Finally, an unexpected sharp decline in the oil price could undermine fiscal performance and the balance-of-payments position. However, the authorities have stressed their commitment to take the necessary actions to achieve the program objectives and have pointed out their track record over the past few years. 
49. Overall, the staff regards the policy commitments and proposed payments to the Fund under the 2004 SMP to be in line with what would be required for a RAP. Staff, therefore, considers that the program provides an adequate basis for staff monitoring. Furthermore, as and when financing assurances become available, the staff would recommend that in determining the timetable for arrears clearance, the Executive Board take account of the performance under the 2004 SMP (provided that it is satisfactory) and under the 2002 and 2003 SMPs. Finally, in the event that peace is reached in the near future and the appropriate financing assurances are secured, the 2004 SMP should provide the basis for the RAP in the remainder of 2004. 
Table 1. Sudan: Quantitative Indicative Targets, 2003

(In billions of Sudanese dinars; unless otherwise indicated)

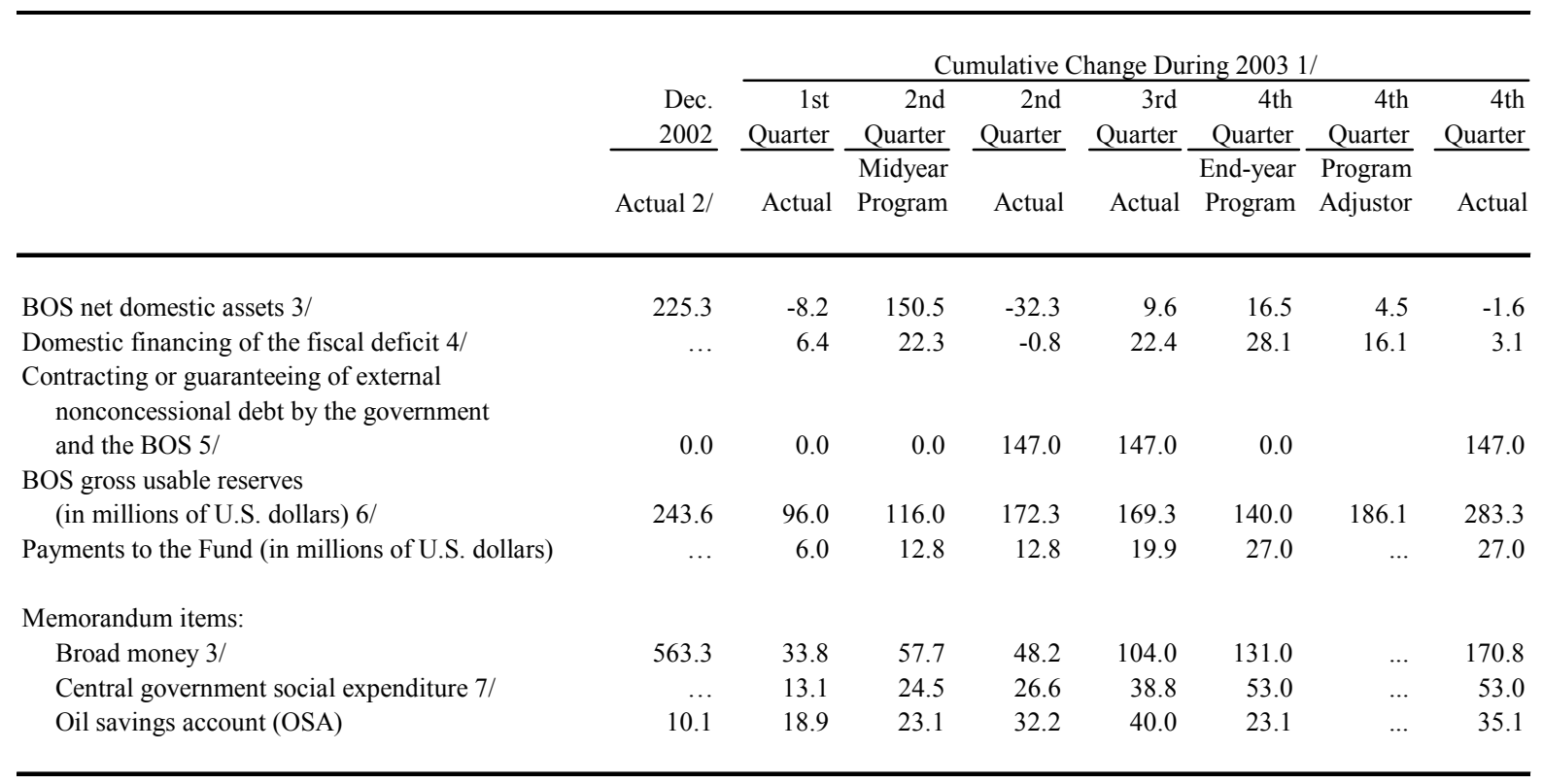

Sources: Sudanese authorities; and Fund staff estimates and projections.

1/ Cumulative change from the end of the previous year.

2/ Outstanding stock at end-of-year.

3/ Based on new presentation of the monetary data, consistent with Fund guidelines, adopted in January 2000. Net BOS financing is defined as borrowing by the government from the BOS (including GMCs) minus central government deposits at the BOS (excluding deposits accumulated in the OSA).

4/ Defined as total net borrowing by the government, including net borrowing from the BOS (including GMCs and changes in deposits of the central government with the BOS), net sales of GMCs outside the BOS, revenues from privatization, and repayments of internal domestic debts.

5/ This indicative target applies not only to debt as defined in point No. 9 of the Guidelines on Performance Criteria with Respect to Foreign Debt (Decision No. 12274 - (00/85), August 24, 2000), but also to commitments contracted or guaranteed, for which value has not been received. Debt will be deemed to be concessional when the currency-specific discount rate (determined by the market-related "commercial interest reference rates" as published by the OECD) applied to the contractual schedule of charges and principal payments, indicates a grant element of at least 35 percent. The indicative target excludes the financing of the Merowe hydropower project.

6/ In the new presentation of the Monetary Authorities' Accounts, gross usable reserves include foreign banknotes in the vaults of the BOS.

7/ Central government expenditure on medical care, health services, poor students' support, supplement to poor consumers of electricity, social and health insurance, and water, health, and education development. 
Table 2. Sudan: Structural Benchmarks for 2003

\begin{tabular}{|c|c|}
\hline Policy Area & Status of Implementation \\
\hline By end-June 2003 & \\
\hline 1. Prepare a comprehensive program to reform the direct tax system. & Done \\
\hline $\begin{array}{l}\text { 2. Strengthen the fiscal reporting system with the aim of producing accurate } \\
\text { monthly consolidated accounts within three weeks of the end of the month. } \\
\text { Develop a weekly flash reporting system estimating key fiscal data. }\end{array}$ & Under way \\
\hline 3. Establish the debt management units (external and internal). & Done \\
\hline 4. Establish the monetary operations unit in the BOS. & Done \\
\hline 5. Submit the anti-money laundering law to parliament. & Done \\
\hline By end-December 2003 & \\
\hline 6. Establish a Cash Management Unit at the ministry of finance. & Not done \\
\hline $\begin{array}{l}\text { 7. Prepare a rolling medium-term budget in tandem with the preparation of the } \\
2004 \text { budget. }\end{array}$ & Done \\
\hline $\begin{array}{l}\text { 8. Enhance oil sector transparency by auditing the subsidiaries of Sudan } \\
\text { Petroleum Company and initiating an accounting system reform program. }\end{array}$ & Not done \\
\hline 9. Prepare a comprehensive external debt policy statement and guidelines. & Not done \\
\hline $\begin{array}{l}\text { 10. Submit to parliament amendments to the BOS Law and the Law Regulating } \\
\text { Banking Activity. }\end{array}$ & Done \\
\hline 11. Complete preparations to point of sale for Bank of Khartoum. & Done \\
\hline $\begin{array}{l}\text { 12. Conduct a study, with Fund technical assistance, examining the introduction } \\
\text { of a market-based mechanism for hedging agricultural finance risks, including } \\
\text { possibly through the establishment of commodity future markets for agricultural } \\
\text { products. }\end{array}$ & Done \\
\hline
\end{tabular}


Table 3. Sudan: Selected Economic and Financial Indicators, 2001-04

\begin{tabular}{|c|c|c|c|c|}
\hline & \multicolumn{3}{|c|}{ Actual 1/ } & \multirow{2}{*}{$\frac{\text { Projections }}{2004}$} \\
\hline & 2001 & 2002 & 2003 & \\
\hline & \multicolumn{4}{|c|}{ (Annual changes in percent; unless otherwise indicated) } \\
\hline \multicolumn{5}{|l|}{ National income, production, and prices } \\
\hline Nominal GDP (in billions of Sudanese dinars) & 3,376 & 3,876 & 4,426 & 5,024 \\
\hline Real GDP growth & 6.1 & 6.0 & 6.0 & 6.6 \\
\hline Real non-oil GDP growth & 4.8 & 5.0 & 5.5 & 5.8 \\
\hline Average CPI inflation & 4.9 & 8.3 & 7.7 & 6.5 \\
\hline 12-month CPI inflation (end of period) & 7.4 & 8.3 & 8.3 & 6.5 \\
\hline & \multicolumn{4}{|c|}{ (In percent of GDP) } \\
\hline \multicolumn{5}{|l|}{ Investment and savings } \\
\hline Gross domestic investment & 18.3 & 19.1 & 19.1 & 21.6 \\
\hline Government sector & 2.3 & 3.1 & 3.1 & 5.6 \\
\hline Nongovernment sector & 16.0 & 16.0 & 16.0 & 16.0 \\
\hline Gross domestic savings & 10.3 & 12.8 & 14.6 & 16.3 \\
\hline Government sector & 2.2 & 3.5 & 5.7 & 5.7 \\
\hline Nongovernment sector & 8.1 & 9.2 & 8.9 & 10.7 \\
\hline Net exports of goods and nonfactor services & -8.0 & -6.3 & -4.4 & -5.3 \\
\hline \multicolumn{5}{|l|}{ Central government operations } \\
\hline Total revenue & 11.0 & 12.1 & 16.8 & 18.7 \\
\hline Total expenditure & 11.9 & 13.0 & 15.8 & 19.9 \\
\hline \multirow[t]{2}{*}{ Overall balance (cash) 2/ } & -0.9 & -0.8 & 1.0 & -1.2 \\
\hline & \multicolumn{4}{|c|}{ (Changes in percent of beginning broad money stock) } \\
\hline Money and credit 3/ & & & & \\
\hline Net foreign assets (excluding valuation changes) & -8.6 & 23.2 & 13.7 & 12.4 \\
\hline Net domestic assets & 33.3 & 7.2 & 16.6 & 9.6 \\
\hline Net domestic credit & 25.9 & 8.7 & 16.7 & 8.3 \\
\hline Net claims on central government & 9.0 & -1.5 & -3.4 & -3.1 \\
\hline Claims on nongovernment sectors & 16.9 & 10.2 & 20.1 & 11.4 \\
\hline Other items (net) & 7.4 & -1.5 & -0.1 & 1.3 \\
\hline Broad money & 24.7 & 30.3 & 30.3 & 22.0 \\
\hline Reserve money (change in percent) & 3.7 & 22.0 & 26.6 & 20.2 \\
\hline \multirow[t]{2}{*}{ Velocity (average) } & 7.7 & 7.6 & 6.9 & 5.6 \\
\hline & \multicolumn{4}{|c|}{ (In millions of U.S. dollars; unless otherwise indicated) } \\
\hline \multicolumn{5}{|l|}{ External sector } \\
\hline Exports, f.o.b. & 1,699 & 1,949 & 2,577 & 3,001 \\
\hline Imports, f.o.b & $-2,031$ & $-2,153$ & $-2,536$ & $-3,032$ \\
\hline External current account balance 4/ & $-1,289$ & -918 & -827 & $-1,000$ \\
\hline In percent of GDP & -9.9 & -6.2 & -4.9 & -5.2 \\
\hline Terms of trade (non-oil exports/non-oil imports) & -3.0 & -3.6 & 13.7 & -2.2 \\
\hline Real effective exchange rate (end of period, change in percent) & 8.0 & -2.0 & -4.5 & $\ldots$ \\
\hline Official exchange rate (end of period, SD/US\$) & 261.4 & 261.7 & 260.4 & $\ldots$ \\
\hline \multicolumn{5}{|l|}{ Total external debt service (percent of current receipts) } \\
\hline Commitment basis & 38.4 & 24.1 & 24.2 & 22.9 \\
\hline Actual payments & 5.1 & 3.9 & 6.1 & 6.5 \\
\hline External debt (in billions of U.S. dollars) & 20.9 & 23.6 & 24.1 & 25.3 \\
\hline BOS gross usable reserves (in millions of U.S. dollars) & 44.9 & 243.6 & 526.9 & 806.9 \\
\hline In months of next year's imports & 0.2 & 1.0 & 1.8 & 2.5 \\
\hline Crude oil export price (US\$ per barrel) & 22.0 & 23.0 & 27.0 & 28.2 \\
\hline
\end{tabular}

Sources: Fund staff estimates and projections based on information provided by the Sudanese authorities.

1/ National accounts data for 2001-03 are Fund staff estimates.

2/ Including the oil savings account (OSA).

3/ Definition of broad money in 2001 is based on the new presentation of monetary aggregates, adopted in January 2000.

4/ On cash basis. 
Table 4. Sudan: Summary Balance of Payments, 2000-05

\begin{tabular}{|c|c|c|c|c|c|c|c|}
\hline & \multicolumn{3}{|c|}{ Act. } & \multirow{2}{*}{$\begin{array}{r}\text { Est. } \\
2003\end{array}$} & \multirow{2}{*}{$\frac{\text { Prog. }}{2003}$} & \multirow{2}{*}{$\frac{\text { Proj. }}{2004}$} & \multirow{2}{*}{$\frac{\text { Proj. }}{2005}$} \\
\hline & 2000 & 2001 & 2002 & & & & \\
\hline & \multicolumn{7}{|c|}{ (In millions of U.S. dollars) } \\
\hline Current account balance & $-1,840$ & $-2,116$ & $-1,472$ & $-1,457$ & $-1,602$ & $-1,649$ & $-1,695$ \\
\hline (Cash basis) & -632 & $-1,289$ & -918 & -827 & $-1,065$ & $-1,000$ & $-1,003$ \\
\hline Trade balance & 230 & -332 & -204 & 40 & 0.4 & -31 & -70 \\
\hline Exports, f.o.b. & 1,864 & 1,699 & 1,949 & 2,577 & 2,324 & 3,001 & 3,197 \\
\hline Crude oil & 1,298 & 1,268 & 1,397 & 1,968 & 1,694 & 2,339 & 2,413 \\
\hline Petroleum products & 110 & 109 & 114 & 114 & 116 & 116 & 203 \\
\hline Non-oil products & 456 & 322 & 438 & 494 & 514 & 546 & 581 \\
\hline Imports, f.o.b. 1/ & $-1,634$ & $-2,031$ & $-2,153$ & $-2,536$ & $-2,323$ & $-3,032$ & $-3,268$ \\
\hline Foodstuffs & -340 & -416 & -388 & -370 & -445 & -412 & -426 \\
\hline Machinery and transport equipment & -482 & -679 & -771 & -992 & -821 & $-1,234$ & $-1,364$ \\
\hline Manufactured goods & -294 & -359 & -488 & -641 & -555 & -823 & -883 \\
\hline Other & -411 & -447 & -390 & -402 & -379 & -457 & -534 \\
\hline Services (net) & -527 & -714 & -724 & -794 & -796 & -972 & $-1,067$ \\
\hline Receipts & 28 & 15 & 47 & 36 & 52 & 38 & 40 \\
\hline Payments & -555 & -729 & -771 & -831 & -848 & $-1,011$ & $-1,107$ \\
\hline Of which: oil transportation costs & -251 & -367 & -414 & -395 & -453 & -471 & -521 \\
\hline Income (net) & $-1,887$ & $-1,443$ & $-1,210$ & $-1,422$ & $-1,397$ & $-1,466$ & $-1,524$ \\
\hline Receipts & 5 & 18 & 19 & 10 & 19 & 18 & 31 \\
\hline Payments & $-1,269$ & -892 & -599 & -691 & -637 & -725 & -787 \\
\hline Of which: public interest due $2 /$ & $-1,253$ & -880 & -583 & -690 & -627 & -714 & -776 \\
\hline Of which: interest cash payments & -45 & -53 & -29 & -60 & -90 & -65 & -84 \\
\hline Oil-related expenses $3 /$ & -623 & -568 & -631 & -740 & -778 & -759 & -768 \\
\hline Current transfers (net) & 344 & 373 & 666 & 718 & 590 & 821 & 967 \\
\hline Private transfers & 315 & 366 & 634 & 708 & 557 & 761 & 817 \\
\hline Public transfers & 29 & 6 & 32 & 10 & 33 & 60 & 150 \\
\hline Capital account & 21 & 2 & 2 & 0 & 0 & 0 & 0 \\
\hline Financial account (net) & 3 & 522 & 556 & 1,072 & 1,092 & 1,219 & 1,295 \\
\hline Disbursements & 41 & 22 & 30 & 85 & 144 & 370 & 365 \\
\hline Amortization & -265 & -157 & -166 & -239 & -215 & -280 & -290 \\
\hline Of which: cash payments & -51 & -53 & -84 & -161 & -90 & -201 & -295 \\
\hline Short-term capital flows (net) 4/ & 117 & 120 & 222 & 139 & 129 & 28 & 56 \\
\hline Commercial banks NFA (increase -) & -18 & -37 & -163 & -5 & -34 & -35 & 0 \\
\hline FDI and portfolio (net) & 128 & 574 & 633 & 1,092 & 1,068 & 1,136 & 1,164 \\
\hline Errors and omissions & 594 & 712 & 481 & 89 & 0 & 0 & 0 \\
\hline Overall balance & $-1,223$ & -881 & -433 & -296 & -511 & -430 & -399 \\
\hline Change in official reserves (increase -) & -109 & 0 & -244 & -434 & -153 & -298 & -287 \\
\hline IMF (net) & -28 & -24 & -8 & -12 & -13 & -18 & -37 \\
\hline Total payments to the Fund & -63 & -55 & -24 & -26 & -27 & -30 & -50 \\
\hline Change in arrears on charges & 35 & 31 & 16 & 14 & 14 & 12 & 13 \\
\hline Usable foreign reserves (increase -) & -82 & 90 & -199 & -283 & -140 & -280 & -250 \\
\hline Other foreign reserves (increase -) & 0 & -66 & -37 & -139 & $\ldots$ & 0 & 0 \\
\hline Exceptional financing & 1,332 & 881 & 677 & 730 & 663 & 728 & 687 \\
\hline Change in non-Fund arrears & 1,332 & 881 & 636 & 708 & 648 & 728 & 0 \\
\hline Debt relief & 0 & 0 & 0 & 0 & 0 & 0 & 687 \\
\hline Privatization receipts & 0 & 0 & 41 & 22 & 15 & 0 & 0 \\
\hline Financing gap & 0 & 0 & 0 & 0 & 0 & 0 & 0 \\
\hline
\end{tabular}


Table 4. Sudan: Summary Balance of Payments, 2000-05 (concluded)

\begin{tabular}{|c|c|c|c|c|c|c|c|}
\hline & \multicolumn{3}{|c|}{ Act. } & \multirow{2}{*}{$\frac{\text { Est. }}{2003}$} & \multirow{2}{*}{$\frac{\text { Prog. }}{2003}$} & \multirow{2}{*}{$\frac{\text { Proj. }}{2004}$} & \multirow{2}{*}{$\frac{\text { Proj }}{2005}$} \\
\hline & 2000 & 2001 & 2002 & & & & \\
\hline & \multicolumn{7}{|c|}{ (In percent of GDP) } \\
\hline \multicolumn{8}{|l|}{ Memorandum items: } \\
\hline Current account & -15.1 & -16.2 & -10.0 & -8.6 & -10.5 & -8.7 & -7.9 \\
\hline (Cash basis) & -5.2 & -9.9 & -6.2 & -4.9 & -7.0 & -5.2 & -4.7 \\
\hline Current transfers (net) & 2.8 & 2.9 & 4.5 & 4.2 & 3.9 & 4.3 & 4.5 \\
\hline Of which: private transfers & 2.6 & 2.8 & 4.3 & 4.2 & 3.7 & 4.0 & 3.8 \\
\hline Gross usable reserves (in millions of U.S. dollars) & 135 & 45 & 244 & 527 & 384 & 807 & 1,057 \\
\hline (In months of next year's imports) & 0.7 & 0.2 & 1.0 & 1.8 & 1.7 & 2.5 & 2.9 \\
\hline & \multicolumn{7}{|c|}{ (Percent change) } \\
\hline Exports (value) & 139.0 & -8.9 & 14.7 & 32.2 & 20.6 & 16.5 & 6.6 \\
\hline Non-oil export (value) & -9.6 & -29.3 & 36.0 & 12.8 & 17.5 & 10.4 & 6.5 \\
\hline Non-oil export (volume) & -5.8 & -23.0 & 40.1 & -8.2 & 5.0 & 6.4 & 7.4 \\
\hline Imports (value) & 8.9 & 24.3 & 6.0 & 17.8 & 7.9 & 19.5 & 7.8 \\
\hline Import volume & 4.2 & 35.4 & 4.7 & 6.5 & 0.9 & 13.5 & 11.3 \\
\hline Import volume (excluding petroleum products) & 18.8 & 31.6 & 5.6 & 9.2 & 0.2 & 15.2 & 9.1 \\
\hline Terms of trade (non-oil exports/non-oil imports) & -0.7 & -3.0 & -3.6 & 13.7 & 3.8 & -2.2 & -1.1 \\
\hline Crude oil exports (volume, in thousands of barrels) & 49,242 & 56,152 & 62,179 & 72,921 & 62,179 & 82,940 & 95,740 \\
\hline Crude oil price (US\$ per barrel) & 27.2 & 22.0 & 23.0 & 27.0 & $\ldots$ & 28.2 & 25.2 \\
\hline
\end{tabular}

Sources: Sudanese authorities; and Fund staff estimates and projections.

1/ Import figures were revised up to reflect improved coverage.

2/ Includes estimates of late interest accrued during the year and Fund special charges.

3 / Includes payments to oil companies related to profit-sharing arrangements.

4/ Net short-term trade and other credit facilities of the BOS and commercial banks. 
Table 5. Sudan: Central Government Operations, 1999-2004

\begin{tabular}{|c|c|c|c|c|c|c|c|}
\hline & \multicolumn{4}{|c|}{ Actual } & \multirow{2}{*}{$\frac{\text { Program }}{2003}$} & \multirow{2}{*}{$\frac{\text { Actual }}{2003}$} & \multirow{2}{*}{$\frac{\text { Program }}{2004}$} \\
\hline & 1999 & 2000 & 2001 & 2002 & & & \\
\hline & \multicolumn{7}{|c|}{ (In billions of Sudanese dinars) } \\
\hline Total revenues & 205.5 & 326.3 & 370.0 & 470.7 & 598.5 & 741.9 & 937.1 \\
\hline Tax revenue & 153.3 & 157.4 & 188.7 & 213.4 & 260.9 & 270.0 & 372.2 \\
\hline Direct taxes & 36.1 & 37.4 & 41.5 & 41.2 & 46.6 & 52.3 & 68.5 \\
\hline Indirect taxes & 117.2 & 120.0 & 147.2 & 172.2 & 214.3 & 217.7 & 303.7 \\
\hline Taxes on international transactions & 84.4 & 69.6 & 77.1 & 97.6 & 103.8 & 112.7 & 128.6 \\
\hline Excise duties & 32.8 & 34.3 & 32.5 & 33.2 & 48.5 & 49.3 & 102.5 \\
\hline VAT & 0.0 & 16.1 & 37.7 & 41.4 & 62.0 & 55.7 & 72.6 \\
\hline Nontax revenue & 52.2 & 169.0 & 181.3 & 257.2 & 337.6 & 471.9 & 564.9 \\
\hline Departmental fees & 9.4 & 9.2 & 10.3 & 13.0 & 18.4 & 10.7 & 20.0 \\
\hline National revenues & 42.8 & 159.7 & 171.0 & 244.2 & 319.2 & 461.2 & 544.9 \\
\hline Non-oil & 27.1 & 18.9 & 21.3 & 33.5 & 50.6 & 38.7 & 54.8 \\
\hline Oil & 15.7 & 140.9 & 149.7 & 210.7 & 268.6 & 422.6 & 490.1 \\
\hline Crude Oil & $\ldots$ & $\ldots$ & 148.9 & 182.9 & 241.8 & 389.0 & 490.1 \\
\hline Of which: OSA & $\ldots$ & $\ldots$ & $\ldots$ & 10.1 & 23.1 & 36.0 & 55.5 \\
\hline Profits from sales of petroleum products & $\ldots$ & $\ldots$ & 0.8 & 27.7 & 26.8 & 33.5 & 0.0 \\
\hline Total expenditure & 227.2 & 349.9 & 401.1 & 503.4 & 596.9 & 699.1 & 999.4 \\
\hline Current expenditure & 195.0 & 275.4 & 322.5 & 384.8 & 472.9 & 563.8 & 717.6 \\
\hline Chapter one (wages, salaries, and pensions) & 80.4 & 105.9 & 131.6 & 165.1 & 196.5 & 191.1 & 264.2 \\
\hline Chapter two (other current spending) & 101.8 & 142.8 & 165.9 & 186.8 & 219.3 & 321.3 & 354.4 \\
\hline Debt service paid & 20.2 & 34.6 & 26.2 & 51.1 & 65.2 & 73.0 & 65.2 \\
\hline Goods and services & 37.9 & 53.3 & 48.8 & 50.5 & 53.0 & 54.5 & 83.2 \\
\hline General reserve & 24.9 & 36.8 & 59.5 & 50.4 & 45.7 & 104.0 & 119.7 \\
\hline Other & 18.9 & 18.0 & 31.3 & 34.8 & 55.5 & 89.8 & 86.3 \\
\hline Chapter three (current transfers to states) & 12.8 & 26.8 & 25.0 & 32.9 & 57.1 & 51.4 & 99.0 \\
\hline Capital expenditure & 32.2 & 74.5 & 78.7 & 118.6 & 124.0 & 135.2 & 281.8 \\
\hline Domestically financed $1 /$ & 25.7 & 67.1 & 73.3 & 108.9 & 99.4 & 112.8 & 173.0 \\
\hline Foreign financed & 6.5 & 7.4 & 5.4 & 9.6 & 24.6 & 22.4 & 108.7 \\
\hline Overall deficit (cash basis) & -21.7 & -23.6 & -31.2 & -32.7 & 1.6 & 42.8 & -62.3 \\
\hline Financing & 21.7 & 23.6 & 31.2 & 32.7 & -1.6 & -42.8 & 62.3 \\
\hline Foreign financing 1/ & 8.5 & 11.7 & 5.4 & 9.6 & 1.0 & -15.2 & 73.7 \\
\hline Domestic financing & 26.6 & 8.3 & 39.3 & 8.4 & -2.6 & -29.0 & -11.5 \\
\hline BOS & 28.2 & 6.1 & 28.8 & -22.0 & -13.1 & -31.9 & -45.4 \\
\hline GMCs (net) & 0.0 & 1.2 & 20.1 & -17.4 & 3.3 & -1.0 & 5.0 \\
\hline Temporary advances & 30.8 & 8.2 & 10.0 & 12.9 & 6.7 & 6.6 & 5.0 \\
\hline Deposits & -2.7 & -3.3 & -1.3 & -17.6 & -23.1 & -37.5 & -55.5 \\
\hline Of which: OSA & & & & -10.1 & -23.1 & -36.0 & -55.5 \\
\hline Deposit Money Banks (DMBs) & -3.0 & 1.2 & 2.4 & 15.5 & 5.5 & 15.8 & 22.0 \\
\hline Advances & -0.1 & 0.0 & 0.0 & 0.1 & 0.0 & 3.0 & 0.0 \\
\hline GMCs (net) & 0.1 & 4.0 & 3.2 & 13.4 & 5.5 & 14.2 & 22.0 \\
\hline Deposits & -3.1 & -2.8 & -0.7 & 2.0 & 0.0 & -1.4 & 0.0 \\
\hline Nonbanks & 1.5 & 1.0 & 12.7 & 12.2 & 8.0 & 15.0 & 21.0 \\
\hline Domestic arrear repayments & $\ldots$ & $\ldots$ & -7.0 & -8.4 & -9.0 & -30.0 & -15.0 \\
\hline Privatization & $\ldots$ & $\ldots$ & 2.5 & 11.1 & 6.0 & 2.1 & 6.0 \\
\hline Floats and discrepancies & -13.4 & 3.6 & -13.6 & 13.9 & 0.0 & 1.4 & 0.0 \\
\hline \multicolumn{8}{|l|}{ Memorandum items: } \\
\hline Non-oil revenue $2 /$ & 189.8 & 185.5 & 221.1 & 287.7 & 356.7 & 352.9 & 447.0 \\
\hline Crude oil revenue (excluding the OSA) & 15.7 & 140.9 & 148.9 & 172.9 & 218.7 & 353.1 & 434.6 \\
\hline Non-oil domestic deficit & -30.9 & -157.0 & -174.6 & -206.0 & -215.6 & -323.8 & -443.6 \\
\hline Domestic financing excluding OSA & 26.6 & 8.3 & 39.3 & 18.4 & 20.5 & 7.0 & 44.0 \\
\hline Nominal GDP (at factor cost) & 2,627 & 3,034 & 3,376 & 3,876 & 4,426 & 4,426 & 5,024 \\
\hline
\end{tabular}


Table 5. Sudan: Central Government Operations, 1999-2004 (concluded)

\begin{tabular}{|c|c|c|c|c|c|c|c|}
\hline & \multicolumn{4}{|c|}{ Actual } & \multirow{2}{*}{$\frac{\text { Program }}{2003}$} & \multirow{2}{*}{$\frac{\text { Actual }}{2003}$} & \multirow{2}{*}{$\frac{\text { Program }}{2004}$} \\
\hline & 1999 & 2000 & 2001 & $\overline{2002}$ & & & \\
\hline & \multicolumn{5}{|c|}{ (As percent of GDP) } & & \\
\hline Total revenues & 7.8 & 10.8 & 11.0 & 12.1 & 13.5 & 16.8 & 18.7 \\
\hline Tax revenue & 5.8 & 5.2 & 5.6 & 5.5 & 5.9 & 6.1 & 7.4 \\
\hline Direct taxes & 1.4 & 1.2 & 1.2 & 1.1 & 1.1 & 1.2 & 1.4 \\
\hline Indirect taxes & 4.5 & 4.0 & 4.4 & 4.4 & 4.8 & 4.9 & 6.0 \\
\hline Taxes on international transactions & 3.2 & 2.3 & 2.3 & 2.5 & 2.3 & 2.5 & 2.6 \\
\hline Excise duties & 1.3 & 1.1 & 1.0 & 0.9 & 1.1 & 1.1 & 2.0 \\
\hline VAT & 0.0 & 0.5 & 1.1 & 1.1 & 1.4 & 1.3 & 1.4 \\
\hline Nontax revenue & 2.0 & 5.6 & 5.4 & 6.6 & 7.6 & 10.7 & 11.2 \\
\hline Departmental fees & 0.4 & 0.3 & 0.3 & 0.3 & 0.4 & 0.2 & 0.4 \\
\hline National revenues & 1.6 & 5.3 & 5.1 & 6.3 & 7.2 & 10.4 & 10.8 \\
\hline Non-oil & 1.0 & 0.6 & 0.6 & 0.9 & 1.1 & 0.9 & 1.1 \\
\hline Oil & 0.6 & 4.6 & 4.4 & 5.4 & 6.1 & 9.5 & 9.8 \\
\hline Crude oil & $\ldots$ & $\ldots$ & 4.4 & 4.7 & 5.5 & 8.8 & 9.8 \\
\hline Of which : export & $\ldots$ & $\cdots$ & 1.9 & 2.2 & 3.4 & 6.7 & 7.4 \\
\hline Total expenditure & 8.6 & 11.5 & 11.9 & 13.0 & 13.5 & 15.8 & 19.9 \\
\hline Current expenditure & 7.4 & 9.1 & 9.6 & 9.9 & 10.7 & 12.7 & 14.3 \\
\hline Chapter one (wages, salaries, and pensions) & 3.1 & 3.5 & 3.9 & 4.3 & 4.4 & 4.3 & 5.3 \\
\hline Chapter two (other current spending) & 3.9 & 4.7 & 4.9 & 4.8 & 5.0 & 7.3 & 7.1 \\
\hline Debt service paid & 0.8 & 1.1 & 0.8 & 1.3 & 1.5 & 1.6 & 1.3 \\
\hline Goods and services & 1.4 & 1.8 & 1.4 & 1.3 & 1.2 & 1.2 & 1.7 \\
\hline General reserve & 0.9 & 1.2 & 1.8 & 1.3 & 1.0 & 2.3 & 2.4 \\
\hline Other & 0.7 & 0.6 & 0.9 & 0.9 & 1.3 & 2.0 & 1.7 \\
\hline Chapter three (current transfers to states) & 0.5 & 0.9 & 0.7 & 0.8 & 1.3 & 1.2 & 2.0 \\
\hline Capital expenditure & 1.2 & 2.5 & 2.3 & 3.1 & 2.8 & 3.1 & 5.6 \\
\hline Domestically financed $1 /$ & 1.0 & 2.2 & 2.2 & 2.8 & 2.2 & 2.5 & 3.4 \\
\hline Foreign financed & 0.2 & 0.2 & 0.2 & 0.2 & 0.6 & 0.5 & 2.2 \\
\hline Overall deficit (cash basis) & -0.8 & -0.8 & -0.9 & -0.8 & 0.0 & 1.0 & -1.2 \\
\hline Financing & 0.8 & 0.8 & 0.9 & 0.8 & -0.1 & -1.0 & 1.2 \\
\hline Foreign financing $1 /$ & 0.3 & 0.4 & 0.2 & 0.2 & 0.0 & -0.3 & 1.5 \\
\hline Domestic financing & 1.0 & 0.3 & 1.2 & 0.2 & -0.1 & -0.7 & -0.2 \\
\hline BOS & 1.1 & 0.2 & 0.9 & -0.6 & -0.3 & -0.7 & -0.9 \\
\hline DMBs & -0.1 & 0.0 & 0.1 & 0.4 & 0.1 & 0.4 & 0.4 \\
\hline Nonbanks & 0.1 & 0.0 & 0.4 & 0.3 & 0.2 & 0.3 & 0.4 \\
\hline Domestic arrear repayments & $\ldots$ & $\ldots$ & -0.2 & -0.2 & -0.2 & -0.7 & -0.3 \\
\hline Privatization & $\ldots$ & $\ldots$ & 0.1 & 0.3 & 0.1 & 0.0 & 0.1 \\
\hline Floats and discrepancies & -0.5 & 0.1 & -0.4 & 0.4 & 0.0 & 0.0 & 0.0 \\
\hline \multicolumn{8}{|l|}{ Memorandum items: } \\
\hline Non-oil revenue 2/ & 7.2 & 6.1 & 6.5 & 7.4 & 8.1 & 8.0 & 8.9 \\
\hline Crude oil revenue (excluding OSA) & 0.6 & 4.6 & 4.4 & 4.5 & 4.9 & 8.0 & 8.7 \\
\hline Non-oil domestic deficit & -1.2 & -5.2 & -5.2 & -5.3 & -4.9 & -7.3 & -8.8 \\
\hline Domestic financing (excluding OSA) & 1.0 & 0.3 & 1.2 & 0.5 & 0.5 & 0.2 & 0.9 \\
\hline
\end{tabular}

Sources: Sudanese authorities; and Fund staff estimates and projections.

1/ Repayments for oil projects for 2003 and 2004 hitherto classified as capital participation in refinery have been reclassified as principal payments.

2/ Total revenues less crude oil revenues. 


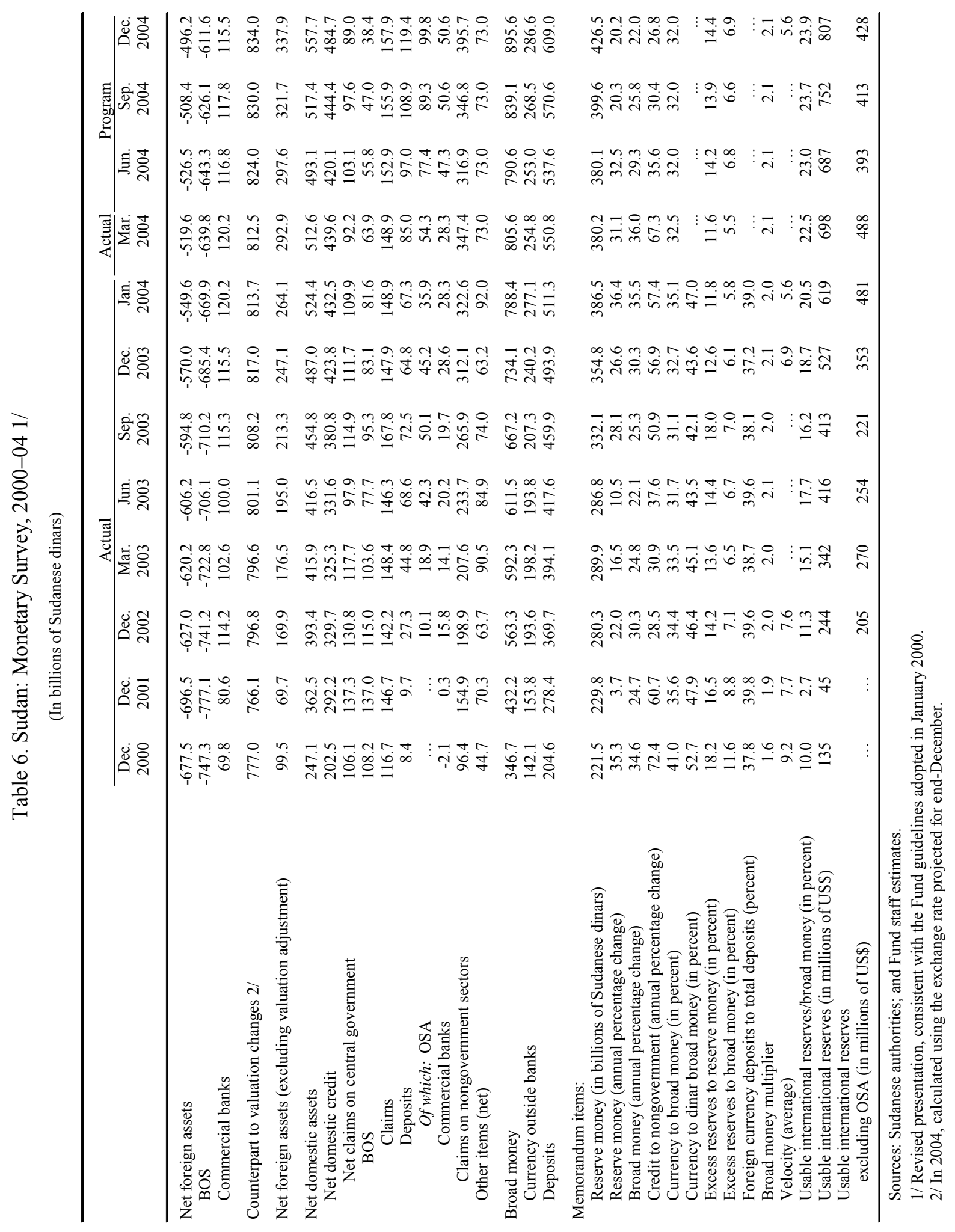




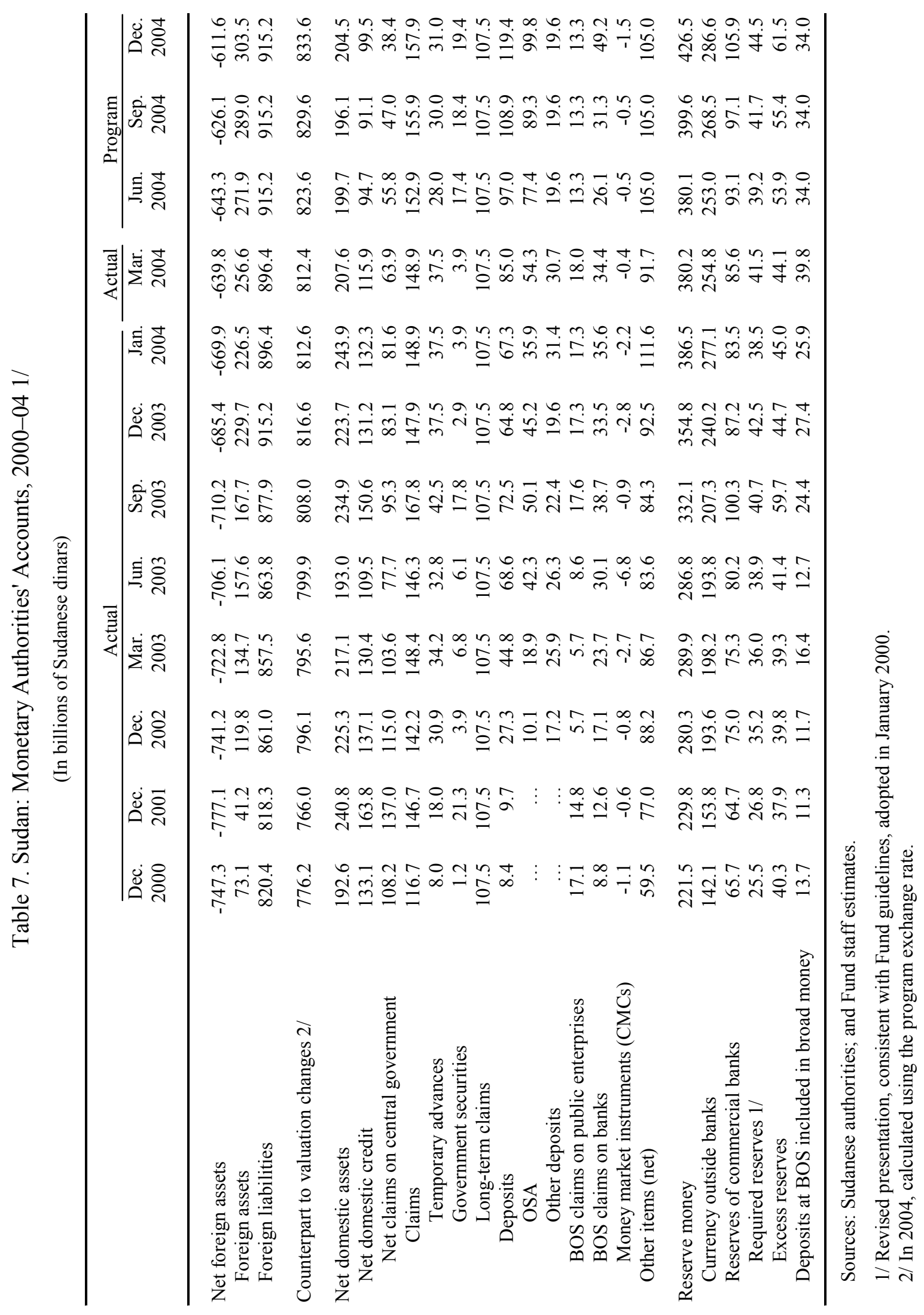




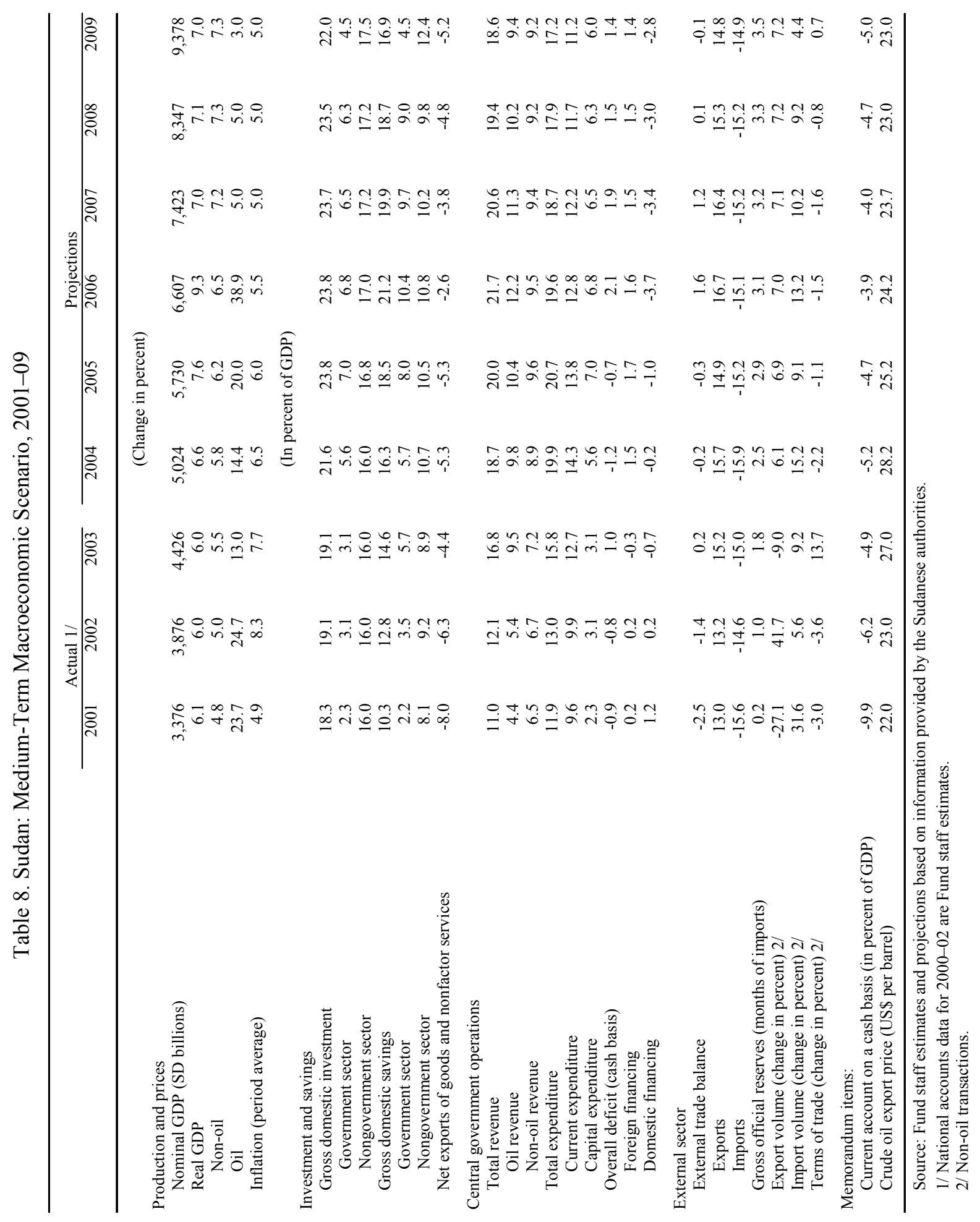


Table 9. Sudan: Indicators of Debt Service Capacity, 2000-04

(In millions of U.S. dollars; unless otherwise indicated)

\begin{tabular}{|c|c|c|c|c|c|}
\hline & \multicolumn{3}{|c|}{ Actual } & \multirow{2}{*}{$\frac{\text { Est. }}{2003}$} & \multirow{2}{*}{$\frac{\text { Proj. }}{2004}$} \\
\hline & 2000 & 2001 & $\overline{2002}$ & & \\
\hline Total debt service paid & 158 & 160 & 137 & 247 & 297 \\
\hline Payments to the Fund & 57 & 55 & 26 & 28 & 30 \\
\hline Charges and interest falling due & 33 & 27 & 17 & 14 & 13 \\
\hline Charges settled & 3 & 3 & 3 & 1 & 2 \\
\hline Reduction in overdue obligations & 54 & 52 & 23 & 26 & 28 \\
\hline Overdue obligations to the Fund & 1,451 & 1,371 & 1,475 & 1,462 & 1,445 \\
\hline \multicolumn{6}{|l|}{ Total debt service paid, in percent of: } \\
\hline Exports of goods and nonfactor services & 8.4 & 9.3 & 6.8 & 9.5 & 9.8 \\
\hline Net current receipts $1 /$ & 13.3 & 13.0 & 11.7 & 15.6 & 14.8 \\
\hline Gross official reserves & 117 & 357 & 56 & 47 & 37 \\
\hline GDP & 1.3 & 1.2 & 0.9 & 1.5 & 1.6 \\
\hline \multicolumn{6}{|l|}{ Payments to the Fund, in percent of: } \\
\hline Exports of goods and nonfactor services & 3.0 & 3.2 & 1.3 & 1.1 & 1.0 \\
\hline Net current receipts $1 /$ & 4.8 & 4.4 & 2.2 & 1.7 & 1.5 \\
\hline Gross official reserves & 42.0 & 122.4 & 10.5 & 5.3 & 3.7 \\
\hline GDP & 0.5 & 0.4 & 0.2 & 0.2 & 0.2 \\
\hline Quota 2/ & 25.6 & 25.8 & 11.1 & 11.7 & 11.0 \\
\hline External debt service & 35.8 & 34.3 & 18.8 & 11.2 & 10.1 \\
\hline \multicolumn{6}{|l|}{ Overdue obligations to the Fund, in percent of: } \\
\hline Exports of goods and nonfactor services & 77 & 80 & 74 & 56 & 48 \\
\hline Net current receipts $1 /$ & 122 & 111 & 126 & 92 & 72 \\
\hline Gross official reserves & 1,076 & 3,056 & 606 & 277 & 179 \\
\hline GDP & 11.9 & 10.5 & 10.0 & 8.6 & 7.6 \\
\hline Quota 2/ & 855 & 808 & 869 & 861 & 852 \\
\hline External debt & 7.3 & 6.5 & 6.2 & 6.1 & 5.7 \\
\hline \multicolumn{6}{|l|}{ Memorandum items: } \\
\hline Exports of goods and services & 1,891 & 1,713 & 1,996 & 2,613 & 3,039 \\
\hline Net current receipts $1 /$ & 1,187 & 1,235 & 1,167 & 1,590 & 1,999 \\
\hline Gross official reserves & 135 & 45 & 244 & 527 & 807 \\
\hline In months of next year's imports & 0.7 & 0.2 & 1.0 & 1.8 & 2.5 \\
\hline GDP (in millions of U.S. dollar) & 12,191 & 13,049 & 14,720 & 16,959 & 19,059 \\
\hline Quota (in millions of SDRs) 2/ & 169.7 & 169.7 & 169.7 & 169.7 & 169.7 \\
\hline External debt (including arrears) & 19,974 & 20,948 & 23,609 & 24,067 & 25,279 \\
\hline Exchange rate (U.S. dollar/SDR, end of period) & 1.3029 & 1.2567 & 1.3595 & 1.3935 & 1.6000 \\
\hline
\end{tabular}

Source: Fund staff estimates.

1 / Current receipts adjusted for oil-related payments for services and transfers to foreign investors, and net of change in reserves.

2/ As percent of Eighth Review Quota. 
Table 10. Sudan: External Financing Requirements and Sources, 2001-04

(In millions of U.S. dollars)

\begin{tabular}{|c|c|c|c|c|}
\hline & \multicolumn{2}{|c|}{ Actual } & \multirow{2}{*}{$\frac{\text { Est. }}{2003}$} & \multirow{2}{*}{$\frac{\text { Proj. }}{2004}$} \\
\hline & 2001 & 2002 & & \\
\hline Gross financing requirements & 2,213 & 1,877 & 2,001 & 2,286 \\
\hline $\begin{array}{l}\text { External current account deficit } \\
\text { (excluding interest payments and official transfers) }\end{array}$ & 2,122 & 1,504 & 1,467 & 1,709 \\
\hline Debt service payments (interest and principal) & 157 & 166 & 239 & 280 \\
\hline Medium- and long-term debt & 157 & 166 & 239 & 280 \\
\hline Public sector & 106 & 166 & 239 & 280 \\
\hline Multilateral 1/ & 55 & 57 & 70 & 54 \\
\hline Bilateral & 51 & 109 & 168 & 226 \\
\hline Commercial banks & 0 & 0 & 0 & 0 \\
\hline Private sector & 51 & 0 & 0 & 0 \\
\hline Short-term debt $2 /$ & 0 & 0 & 0 & 0 \\
\hline Repayment of arrears & 0 & 0 & 0 & 0 \\
\hline Gross reserves accumulation & -90 & 199 & 283 & 280 \\
\hline IMF repurchases and repayments & 24 & 8 & 12 & 18 \\
\hline Expected financing & 2,213 & 1,877 & 2,001 & 2,286 \\
\hline Official transfers and grants & 8 & 34 & 10 & 60 \\
\hline Debt financing & 22 & 30 & 85 & 370 \\
\hline Official creditors & 22 & 30 & 85 & 370 \\
\hline Multilateral & 22 & 17 & 37 & 155 \\
\hline Bilateral & 0 & 13 & 48 & 215 \\
\hline Foreign direct investment, and errors and omissions & 1,286 & 1,155 & 1,203 & 1,136 \\
\hline IMF purchases and disbursements & 0 & 0 & 0 & 0 \\
\hline Accumulation of arrears (exceptional) & 881 & 636 & 708 & 728 \\
\hline Debt relief & 0 & 0 & 0 & 0 \\
\hline Other flows 3 / & 16 & 22 & -5 & -7 \\
\hline Financing gap & 0 & 0 & 0 & 0 \\
\hline
\end{tabular}

Source: Fund staff estimates.

1/ Excluding the IMF.

2/ Original maturity of less than one year. Stock at the end of the previous period.

3/ Includes all other net financial flows. 
Figure 1. Sudan: GDP, Prices, External, and Fiscal Developments, 2000-05

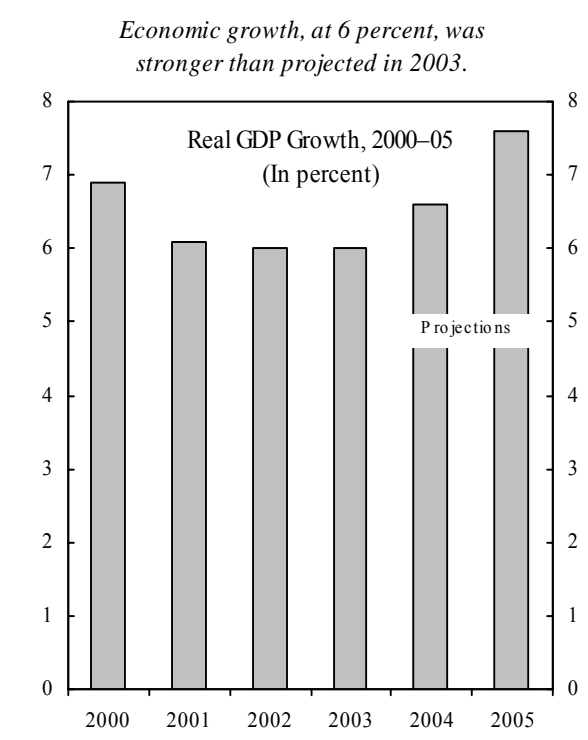

Tight monetary policy in the first three quarters of 2003 led to a slowdown, on average, in inflation in 2003.
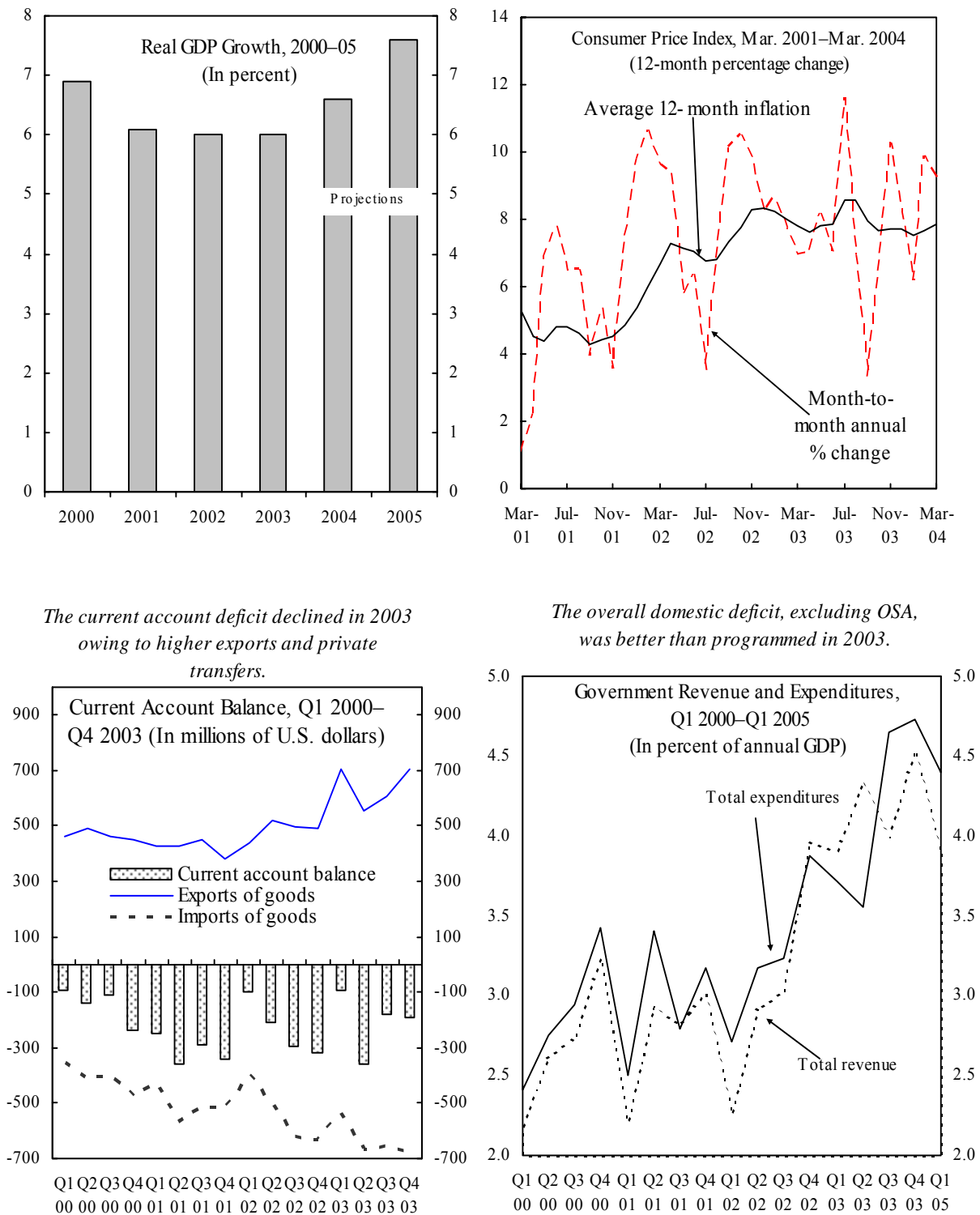

Sources: Sudanese authorities; and Fund staff estimates. 
Figure 2. Sudan: Exchange Rate Indices and International Reserves, January 2001-March 2004

The nominal exchange rate against the U.S. dollar remained stable in 2003, appreciating slightly at the end of the year, while the effective exchange rates

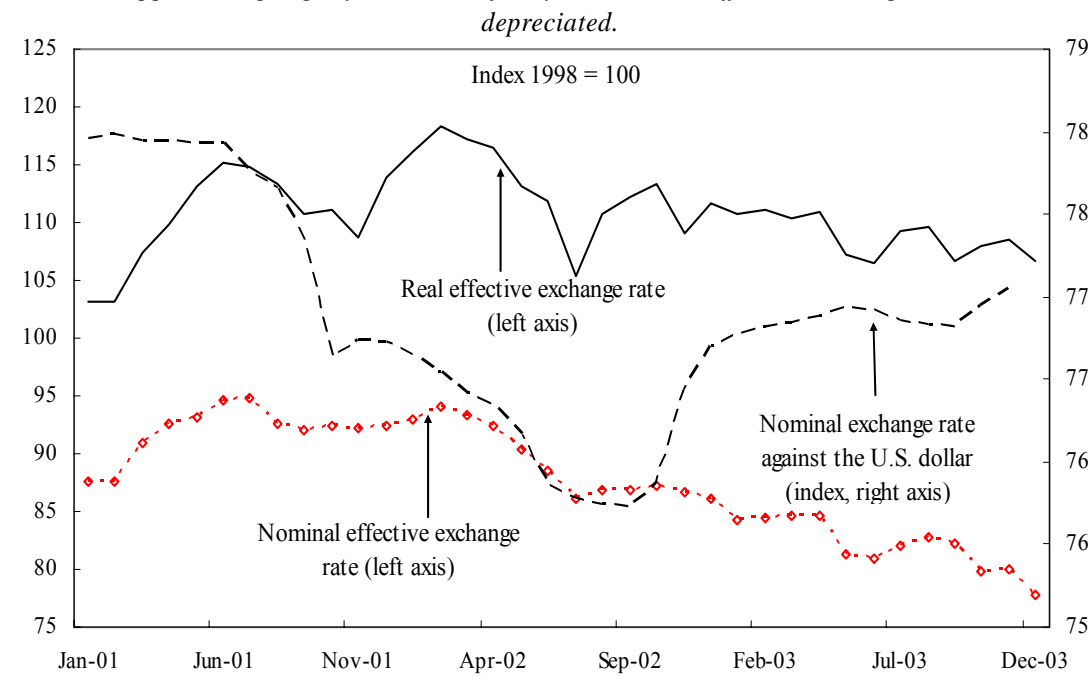

The overall improvement in the balance of payment allowed a strong buildup in international reserves in 2003

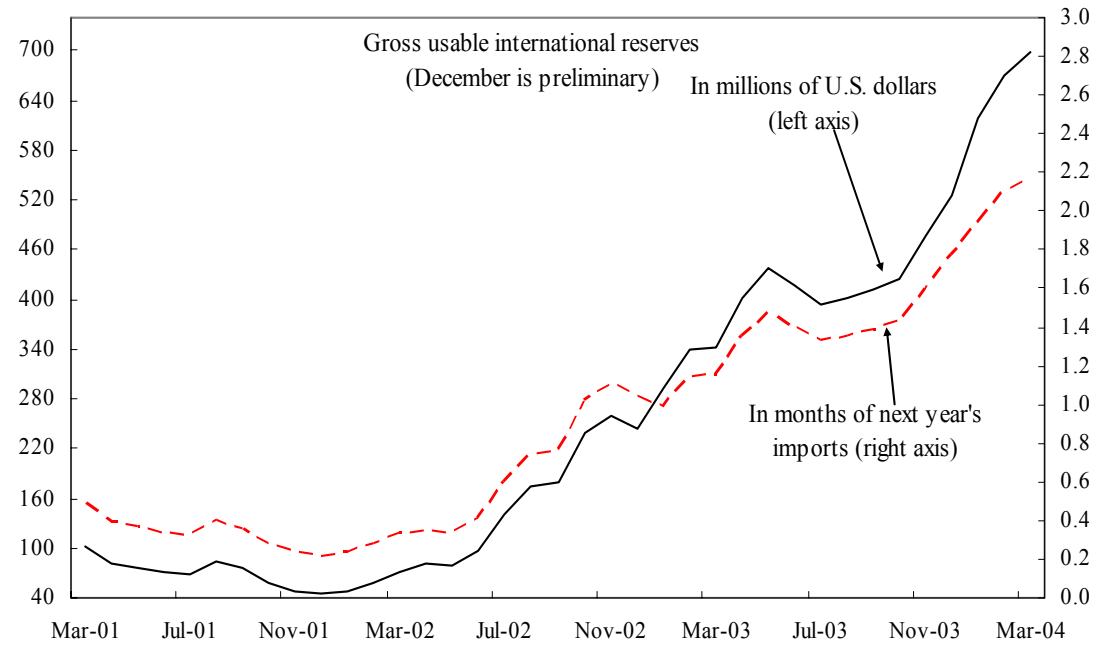

Sources: Bank of Sudan; and Information Notice System, IMF. 
Figure 3. Sudan: Monetary Developments, January 2002-March 2004

Monetary growth accelerated in 2003 owing to large private capital inflows, higher government spending, and BOS lending.

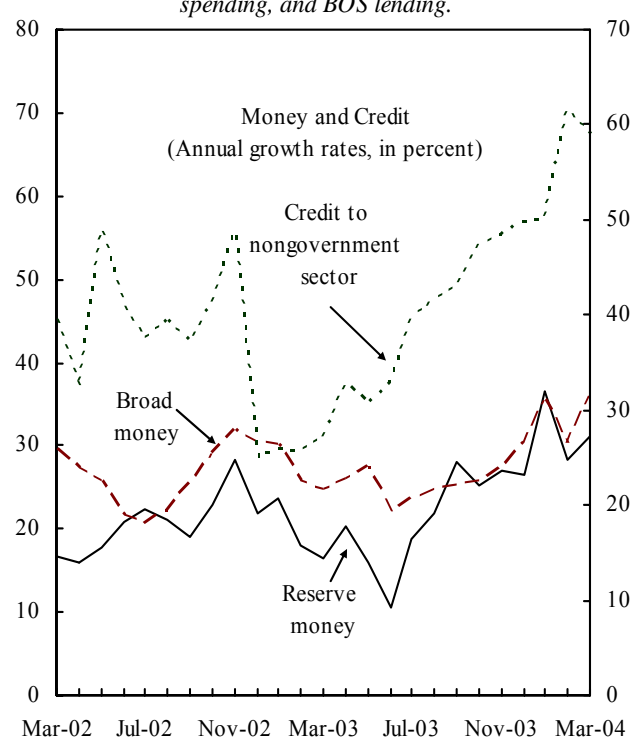

The cost of finance fell in the fourth quarter of 2003.

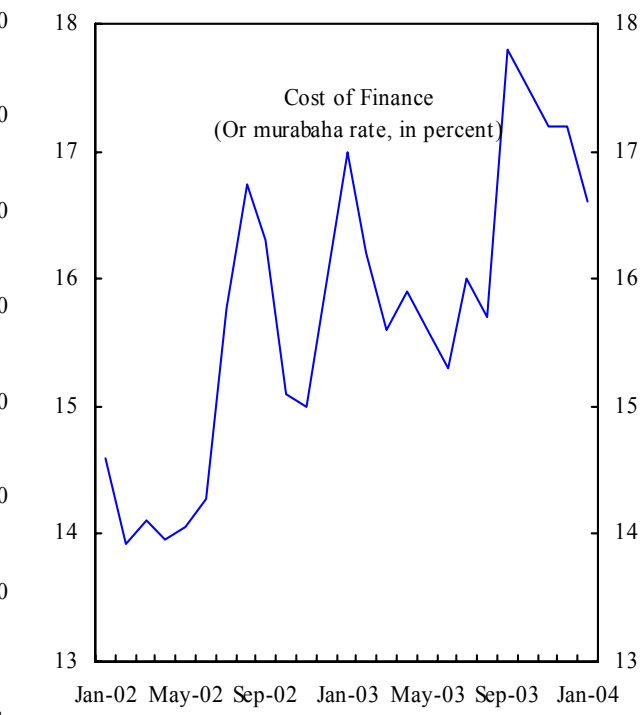

Accumulation of reserves by commercial banks slowed down in the fourth quarter of 2003.

350

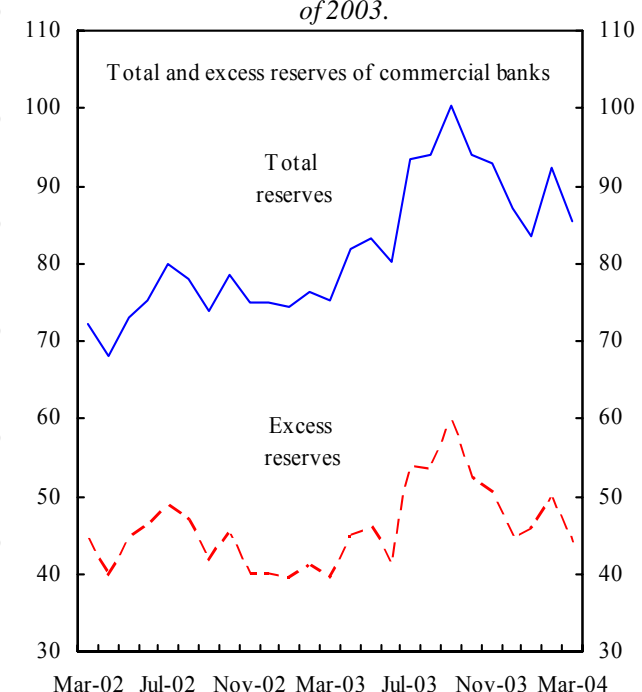

Mar-02 Jul-02 Nov-02 Mar-03 Jul-03 Nov-03 Mar-04

Mar-02 Jul-02 Nov-02 Mar-03 Jul-03 Nov-03 Mar-04

Sources: Bank of Sudan; and Fund staff estimates. 


\section{SUDAN: FUND RELATIONS}

As of March 30, 2004

I. Membership Status: Joined 09/05/57; Article VIII

II. General Resources Account:

Quota

Fund holdings of currency

Reserve position in Fund

III. SDR Department:

Net cumulative allocation

Holdings

IV. Outstanding Purchases and Loans:

Stand-by Arrangements

Extended Arrangements

Contingency and Compensatory

Financing Facility

Trust fund

\begin{tabular}{crr} 
SDR Million & & \% Quota \\
\hline 169.70 & & 100.00 \\
508.90 & & 299.88 \\
0.01 & & 0.01
\end{tabular}

\begin{tabular}{|c|c|}
\hline SDR Million & $\%$ Allocation \\
\hline 52.19 & 100.00 \\
\hline 0.22 & 0.42 \\
\hline
\end{tabular}

\begin{tabular}{|c|c|}
\hline$\underline{\text { SDR Million }}$ & $\%$ Quota \\
\hline 201.72 & 118.87 \\
\hline 113.02 & 66.60 \\
\hline
\end{tabular}

24.44

14.40

59.23

34.90

V. Financial Arrangements:

$\begin{array}{lcccc}\text { Type } & \begin{array}{c}\text { Approval } \\ \text { Date }\end{array} & \begin{array}{c}\text { Expiration } \\ \text { Date }\end{array} & \begin{array}{c}\text { Amount } \\ \text { Approved } \\ (\underline{\text { SDR million }})\end{array} & \begin{array}{c}\text { Amount } \\ \text { Drawn } \\ \text { (SDR million) }\end{array} \\ \text { Stand-by } & 06 / 25 / 1984 & 06 / 24 / 1985 & 90.00 & 20.00 \\ \text { Stand-by } & 02 / 23 / 1983 & 03 / 09 / 1984 & 170.00 & 170.00 \\ \text { Stand-by } & 02 / 22 / 1982 & 02 / 21 / 1983 & 198.00 & 70.00\end{array}$

VI. Projected Obligations to the Fund: (SDR million; based on existing use of resources and present holdings of SDRs):

$$
\begin{aligned}
& \text { Overdue }^{24} \\
& \underline{2 / 29 / 2003} \\
& \hline
\end{aligned}
$$

Principal

Charges/interest

Total

$$
\begin{array}{r}
398.41 \\
673.31 \\
\hline 1,071.72
\end{array}
$$

\begin{tabular}{llll} 
Forthcoming \\
\hline$\underline{2004} \quad \underline{2005} \quad \underline{2006} \quad \underline{2007} \quad \underline{2008}$
\end{tabular}

$\begin{array}{lllll}\underline{6.49} & \underline{8.51} & \underline{8.51} & \underline{8.51} & \underline{8.54} \\ 8.51 & \frac{8.51}{8.54}\end{array}$

\footnotetext{
${ }^{24}$ The projection of charges and interest assumes that overdue principal at the report date (if any) will remain outstanding, but forthcoming obligations will be settled on time.
} 


\section{Exchange Rate Arrangements}

The legal tender is the Sudanese dinar, which replaced the Sudanese pound in proportion SDD 1=LSd 10 in 1999. Since October 1998, the exchange rate system has been unifiedmarket participants determine the exchange rate and trade freely within a unified regulatory framework. In 2001, the foreign exchange market came under pressure and Bank of Sudan (BOS), in an effort to increase the flexibility of the system, introduced a formal band of \pm 1.5 percent (later broadened to 2 percent) around the official rate and began auctioning its foreign exchange within the band. In May 2003, BOS adopted formally a managed-float exchange rate regime. The formal exchange rate band was abandoned, and the auction system was replaced with direct transactions in the interbank market. BOS established an internal limit of \pm 2 percent intraday fluctuations around the average daily market rate that will trigger its intervention. Sudan maintains one inoperative bilateral payments agreement with Egypt and an inoperative payment clearing account with the former Soviet Union.

\section{Article IV Consultation}

Sudan is on a 12-month consultation cycle. The last Article IV consultation discussions were held from August 16 to 28, 2003. The Staff Report (IMF Country Report No.03/390) was discussed by the Executive Board on October 31, 2003.

\section{Technical Assistance}

In January 1995, the Executive Board decided to resume Fund selective technical assistance (TA) to Sudan. Since then, there have been the following TA missions: (i) reform of indirect taxation (August 1995; March, May, and October 1997; May, October, and November 1998; October 1999; and November 2000); (ii) multisector technical assistance in statistics (September/October 1995); (iii) exchange system reform (April and November 1997; May and September 1998); (iv) monetary management and banking supervision (June and November 1997; May, September, and December 1998; May and October 1999; November 2000; and November 2002); (v) government finance statistics (June 1997 and May 1998); (vi) monetary statistics (July 1997; February 2000; May 2000; February 2001; April 2001; and July 2003); (vii) balance-of-payments and monetary statistics (April 1999; and July 2003); (viii) expenditure control and management (September 1997; May 1998; May 2000; and November 2002); (ix) oil sector taxation (October 1999); (x) introduction of the VAT since October 1999; (xi) reform of direct taxation and revenue administration (November 2002; and December 2003); (xii) training course on financial programming and policies (April 2000); (xiii) GDP and CPI statistics (March and September 2002; and February 2003); (xiv) General Data Dissemination System (GDDS) technical assistance (July 2003); (xv) reform of direct taxes and investment incentives (March 2003); (xvi) Medium-Term Budgetary Framework (April 2003); (xvii) monetary policy operations and introduction of a commodities futures/forward market in the agricultural sector (December 2003); and (xviii) Islamic Compliant Monetary Instruments (October 2002). Additionally, an MFD long-term banking supervision resident advisor was assigned to the BOS from May 2001 to May 2003. 


\section{Resident Representative}

The Fund's resident representative in Khartoum was withdrawn in June 1990. 


\title{
SUDAN: RELATIONS WITH THE WORLD BANK ${ }^{25}$
}

\author{
(As of April 2004)
}

The World Bank has no active lending portfolio in Sudan because of Sudan's default on its financial obligations to the Bank, which led to the suspension of disbursements in April 1993. As a result of discussions between the Bank and the Sudanese authorities on the need for Sudan to take steps towards normalizing its relations and establishing a track record with the Bank, the authorities started making "good faith" payments of $\$ 1$ million per month to the Bank starting in July 1999. Monthly payments of an equivalent of $\$ 500,000$ have been made since October 2002. The amount of payments has not been sufficient to prevent a continued accumulation of arrears, which stood at about $\$ 280$ million at the end of 2003 (from $\$ 145$ million at the end of 1999). Sudan's outstanding Bank debt, including arrears, is approximately $\$ 1.3$ billion.

The Bank has been mostly absent from Sudan since 1992. In the 1970s and 1980s, the Bank was a major player in the reconstruction of Sudan, following the Addis Ababa peace agreement of 1972. In the past years, the Bank has occasionally supported small initiatives, on a grant basis, such as the United Nations Children's Fund's (UNICEF) data collection effort. Over the last year, as the prospects for peace have risen, the Bank has formulated a strategy for reengaging with Sudan in the event of peace. This strategy, described in the Sudan Country Reengagement Note (CRN), was discussed by the Executive Board of Directors on July 10, 2003. Main areas of emphasis in the CRN are: knowledge generation and sharing; capacity-building to support policy reform; demonstration projects to improve delivery of social services; and resolution of the debt overhang.

To rebuild its knowledge base, the Bank has completed the first economic report on Sudan in a decade, the Country Economic Memorandum, which focuses on the social and economic developments in Sudan from the early 1990s to present, and the status of macroeconomic, governance, and institutional reforms. Among other interventions, the Bank has engaged the government in a policy dialogue on reforming agriculture and, together with the Fund, has provided technical resource persons for the discussions around wealth-sharing in the peace process. Given the prospects for a peace agreement, intensified work with other donors has also begun as part of donor collaboration in preparing for the post-peace period. In particular, the Bank and the UN have been asked to colead a Joint Assessment Mission (JAM) to assess the reconstruction and rehabilitation needs in the next six years in all of Sudan. The JAM will be undertaken once a comprehensive peace agreement is signed. An assessment report would subsequently inform a donor's pledging conference. Bank and Fund staff have also begun collaboration on resolving the debt issue facing Sudan; this collaboration is expected to increase significantly once a peace agreement is signed.

Contact: Ms. Jill Armstrong, Country Program Coordinator for Sudan

\footnotetext{
${ }^{25}$ Prepared by World Bank staff.
} 


\section{SUDAN: STATISTICAL ISSUES}

Available economic data are sufficient for program monitoring purposes in Sudan. However, there are many areas where further improvements are needed, particularly in compiling national accounts, state budgetary data, and external trade and financial statistics. This appendix discusses outstanding statistical issues by sector.

Based on the recommendations of the July 2003 Statistics Department (STA) mission, the authorities prepared the metadata for participation in the General Data Dissemination System (GDDS). These metadata were posted on the Dissemination Standards Bulletin Board in August 2003. As a participant in the Department for International Development (DFID) project for anglophone African countries, Sudan has been receiving technical assistance on statistical issues. For instance, a technical assistance mission that visited Khartoum in July 2003 encouraged the central bank, the ministry of finance and national economy (MOFNE) as well as the ministry of energy and mining (MEM) to improve interagency coordination in data collection and data-sharing in key areas such as oil-related transactions, and to disseminate up-to-date and comprehensive information through the Bank of Sudan (BOS) web site. In early 2004, Sudan also received assistance for the initial stages of preparation of a statistics master plan.

\section{REAL SECTOR}

Though the compilation and dissemination of the monthly consumer price index (CPI) has been commendable in recent years, the compilation of the national accounts data lags behind. CPI data for the Khartoum area are available on a monthly basis and shortly after the end of each month. CPI data including other states in Sudan are available monthly with a threemonth lag. A peripatetic real sector expert is assisting the authorities in compiling and updating the national accounts.

The national accounts statistics suffer from a lack of basic information for many sectors, including oil, livestock, horticulture, and most services. On the expenditure side, data are lacking on final consumption by households, investment, and changes in stocks. There are no national accounts or industrial production data at subannual frequencies. Furthermore, the annual data are being reported with a lag of over three years. There is an urgent need to rebuild the institutional capacity of the Central Bureau of Statistics (CBS), introduce the 1993 System of National Accounts, conduct a census of agricultural production, and improve coordination among the MOFNE, the MEM, the ministry of agriculture and livestock, and the CBS.

\section{FISCAL SECTOR}

Government finance statistics (GFS) reported to MCD are adequate, with the main revenue, expenditure, and financing items reported on a monthly basis with a lag of about one to two months. Financing items are consistent with the monetary accounts. The reported statistics are for the central government only, and do not include consolidated data on state budgets, 
which are often not available. Data are submitted using economic classification and, while the allocation of resources by MOFNE to the various ministries is reported, their actual expenditures are not. There is a strong need to improve accounting and reporting procedures at MOFNE, introduce the GFS classification, and fully implement the 1997 GFS TA mission recommendations. Data reported for Government Finance Statistics Yearbook are weak and cover only budgetary central government up to 1999 .

\section{MONETARY SECTOR}

Sudan has received significant technical assistance resources to improve progressively the collection, compilation and dissemination of monetary and financial statistics. Following a joint MCD and STA mission in monetary and financial statistics in October 1992, six STA missions were undertaken between 1993 and 2003 to further the development and implementation of the long-term plan of action initiated by the 1992 mission. Consequently, the monetary accounts are broadly acceptable for monitoring purposes; however, STA is concerned that, in the absence of prompt, remedial action as suggested by the July 2003 monetary and financial statistics mission, there may be a reemergence of the problems of overestimation of international reserves and errors and omissions in the determination of net credit to government. This concern is based on findings that there has been only partial implementation of some of the most important recommendations and that some useful measures that had earlier been fully implemented, are now discontinued. For example, balance sheet data of the central bank and commercial banks are reported on a monthly basis and are generally on time. But other items (net) are often large and variable, owing to the grouping of a large volume of transactions into unclassified assets and unclassified liabilities. Moreover, there are frequent classification errors in the reports made by the commercial banks, particularly for consortium financing, which prevents a meaningful analysis of net domestic assets.

The weekly flash reports of the authorities are particularly commendable, with key monetary indicators being reported usually with a one-week lag. Starting January 2003, estimates of the BOS' usable reserves were added. However, there is some divergence between reserve money in the balance sheets and the end-of-month flash reports.

To address these weaknesses, STA agreed to provide a program of peripatetic assistance. The first of these missions (July 2003) noted limited progress in the BOS's implementation of recommendations of past missions and suggested that significant efforts be made by the authorities to follow up on the highest priority measures, including a revision of the guidelines related to consortium financing and compliance, and the establishment of a working group to review the BOS's foreign assets. The second mission was postponed in view of the lack of progress in the implementation of some of these recommendations.

\section{EXTERNAL SECTOR}

Daily exchange rate data are reported to the Fund with minimal lags, but there are several areas for improvement in the external accounts, particularly with regard to foreign direct 
investment, trade, and oil statistics. The BOS's active balances include unusable reserves earmarked for particular purposes such as medicine, oil, and spare part imports, but the composition of these earmarked reserves and their potential usability in the event of a balance of payment need is not clear. The authorities need to provide clarification on items that qualify as international reserves in general, and those earmarked reserves in particular, and should also begin to implement the reserves template.

Regarding import statistics, there are significant discrepancies between the reports of the customs authorities and the BOS. The July 2003 STA mission identified some possible causes of such discrepancies and, in collaboration with authorities, attempted to reconcile the data. The mission reported some progress on implementing the recommendations of the 1999 TA report on balance-of-payments statistics. However, the lack of survey data continues to affect the compilation of important balance-of-payments items such as foreign direct investment.

Medium-term oil production projections and amortization of private sector investment need substantial improvement. The authorities have made some progress in improving oil projections, but appear reluctant to provide more detailed information on the phasing-in and expected production levels of new blocks and on amortization of investment in the oil sector. Total oil reserves available are estimated between 10 to 15 billion barrels, which, at a production rate of 350 thousand barrels a day, would last about 100 years. 


\begin{tabular}{|c|c|c|c|c|c|}
\hline 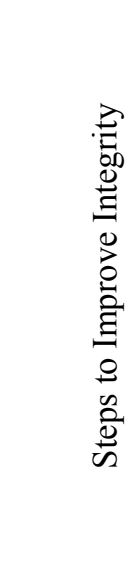 & 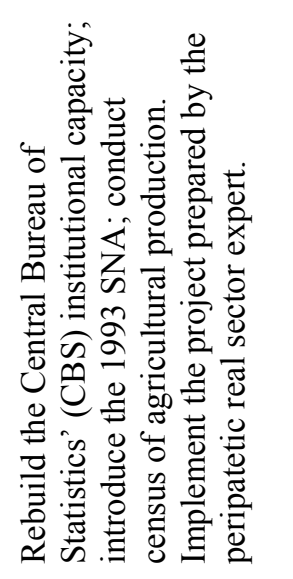 & 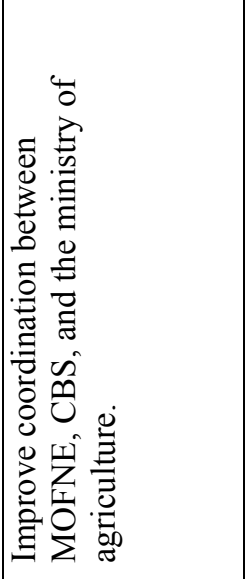 & 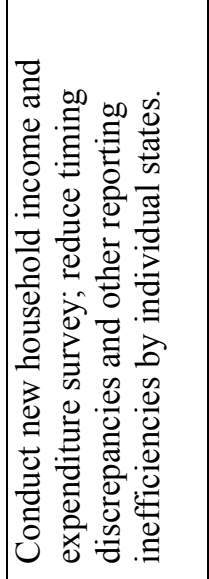 & 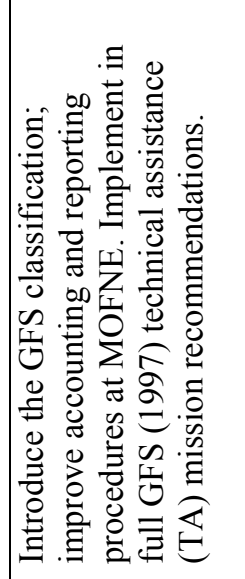 & 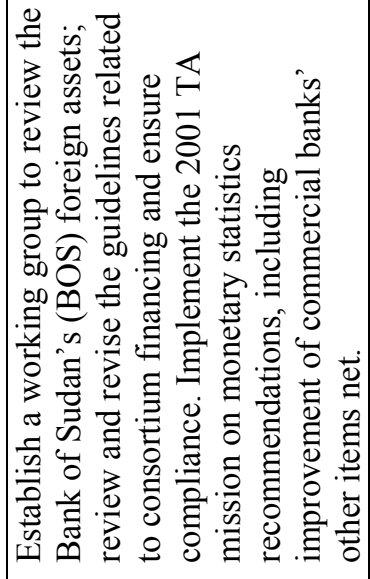 \\
\hline 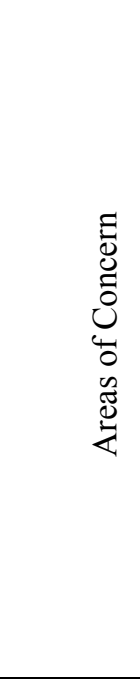 & 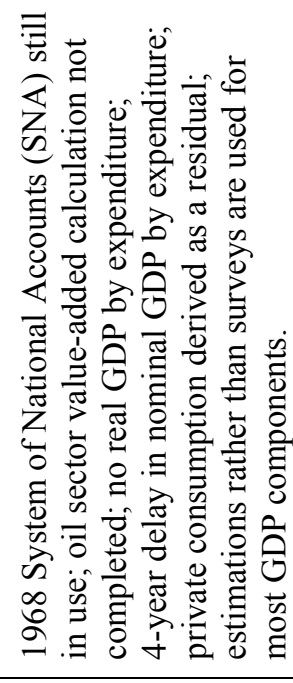 & 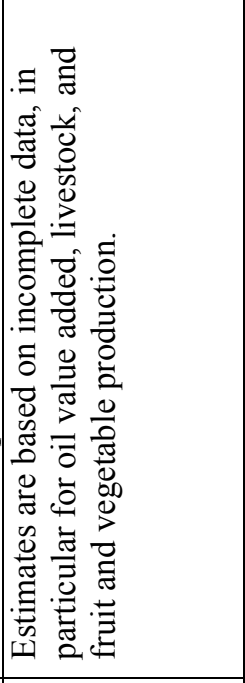 & 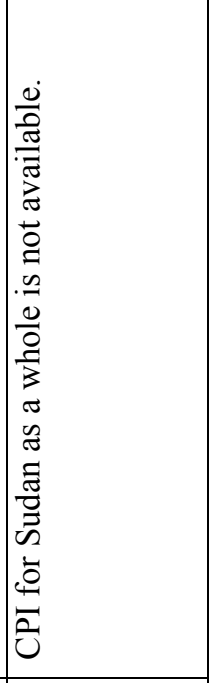 & 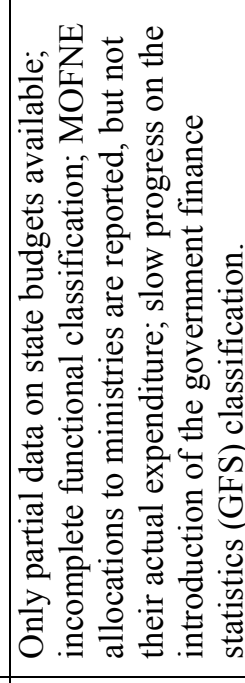 & 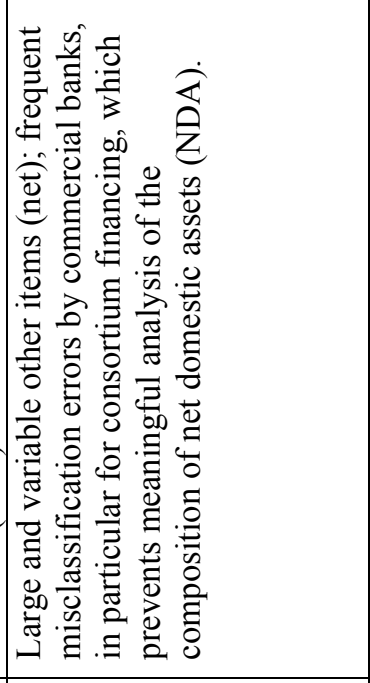 \\
\hline 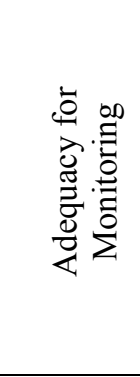 & 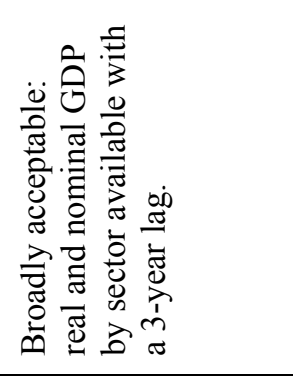 & 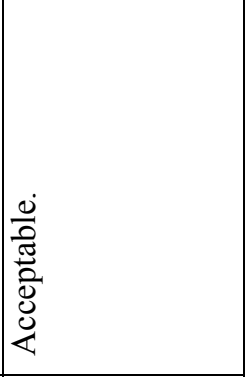 & 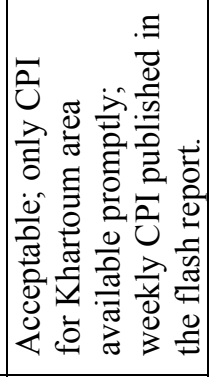 & 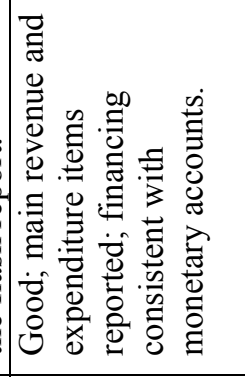 & 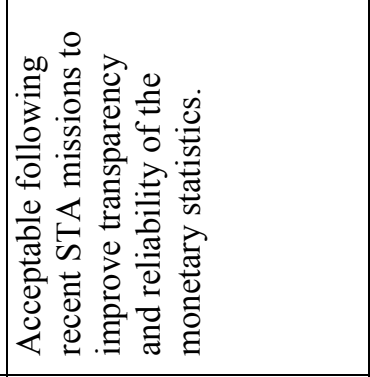 \\
\hline 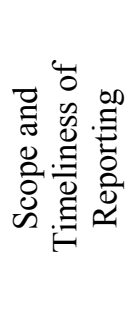 & 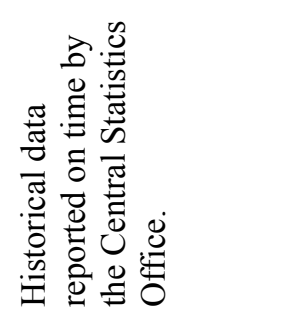 & 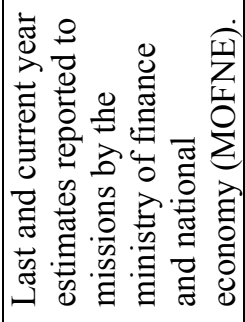 & 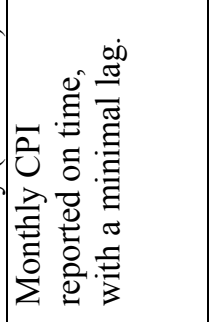 & 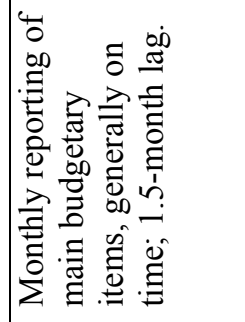 & 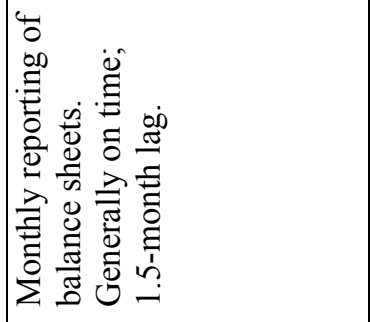 \\
\hline 崩 & \multicolumn{2}{|l|}{ 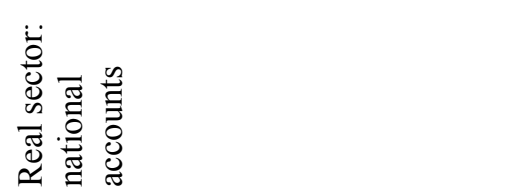 } & 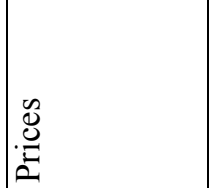 & 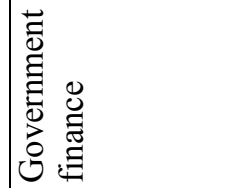 & 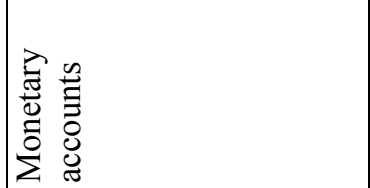 \\
\hline
\end{tabular}




\begin{tabular}{|c|c|c|c|c|c|c|c|}
\hline 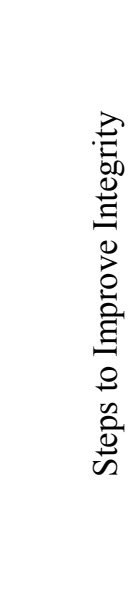 & 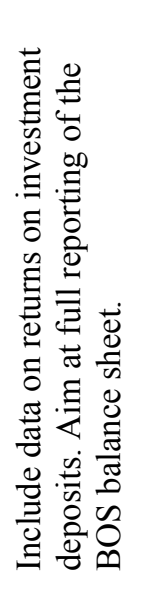 & 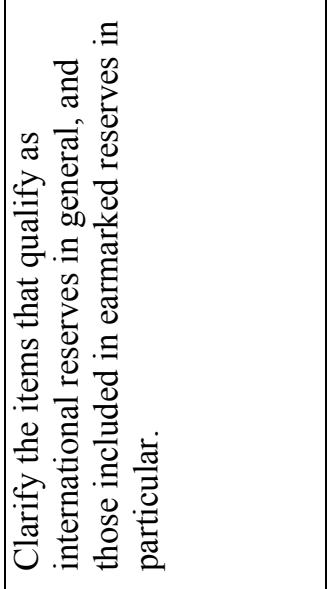 & & 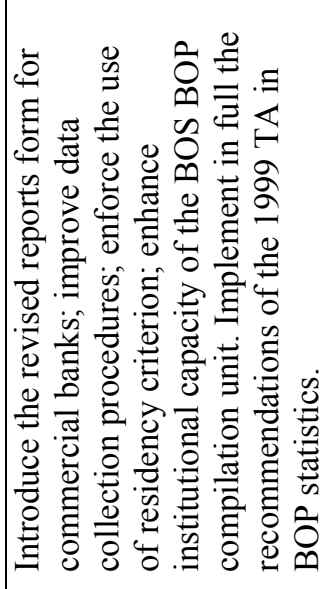 & & 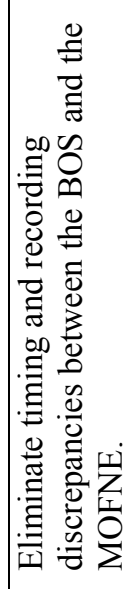 & 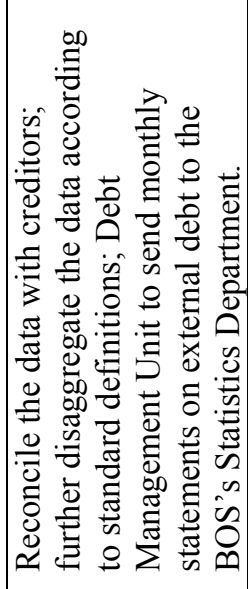 \\
\hline 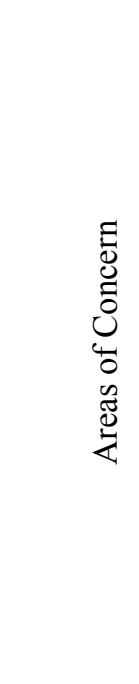 & 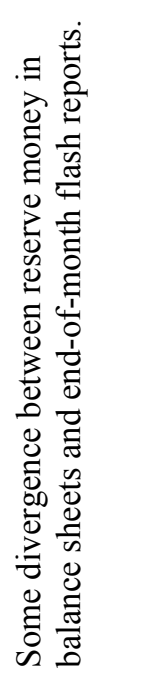 & 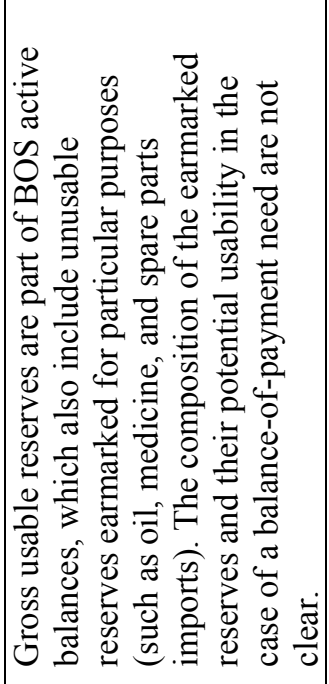 & & 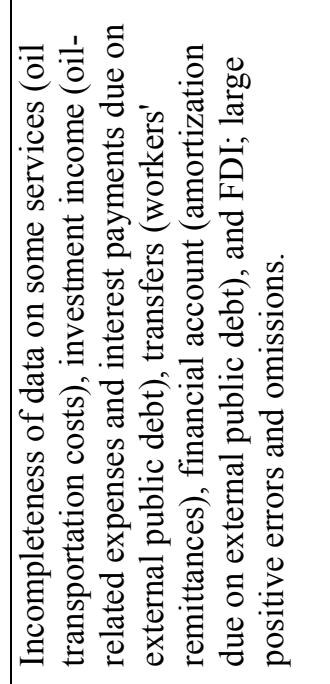 & 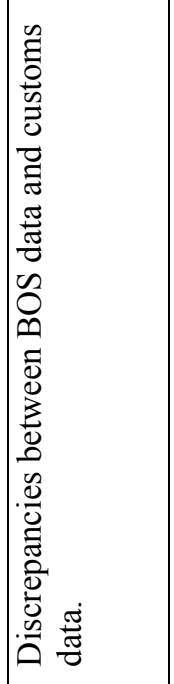 & 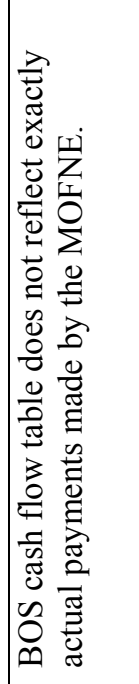 & 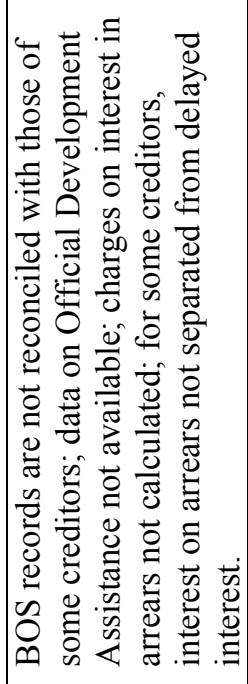 \\
\hline 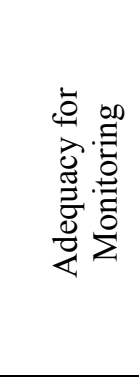 & 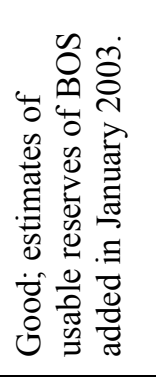 & 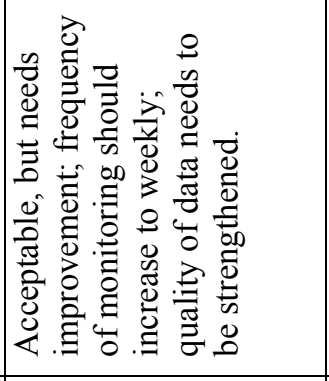 & 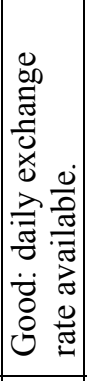 & 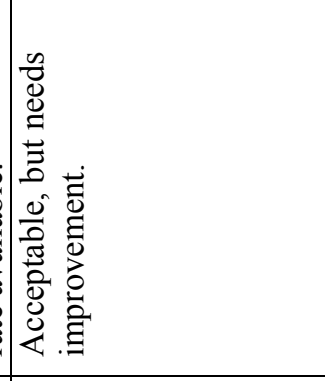 & 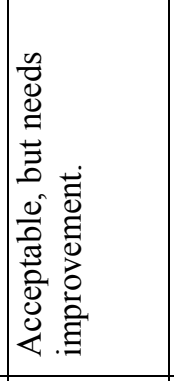 & 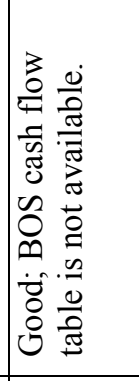 & 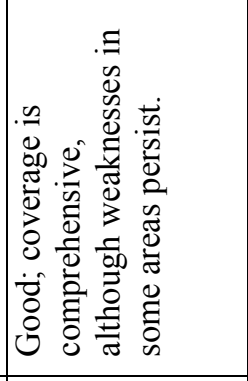 \\
\hline 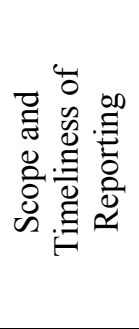 & 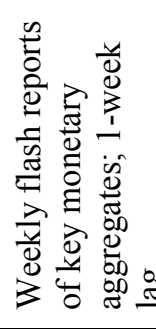 & 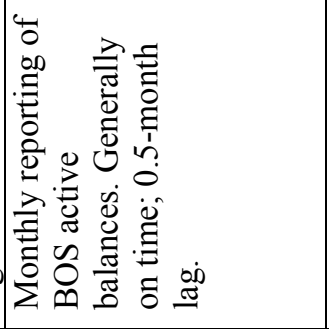 & 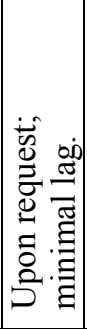 & 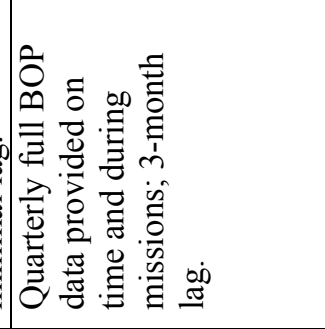 & 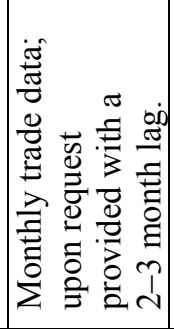 & 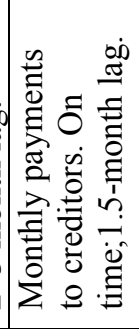 & 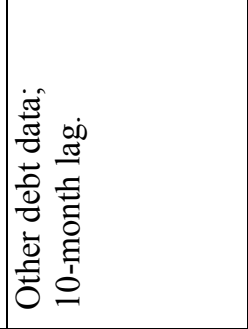 \\
\hline 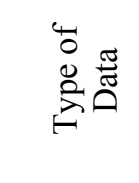 & & 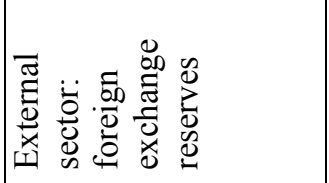 & 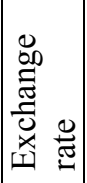 & 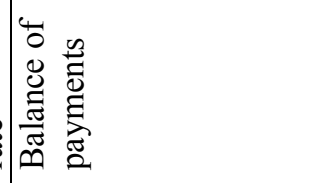 & & 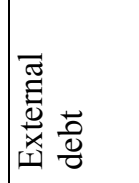 & \\
\hline
\end{tabular}




\begin{tabular}{|c|c|c|c|c|c|c|c|c|c|}
\hline 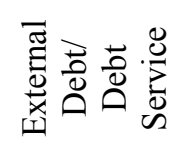 & 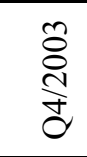 & 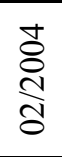 & $\varangle$ & $\varangle$ & $\varangle \begin{array}{r}\widehat{0} \\
\mathscr{\theta}\end{array}$ & 3 & $\infty$ & $\varangle$ & \multirow{13}{*}{ 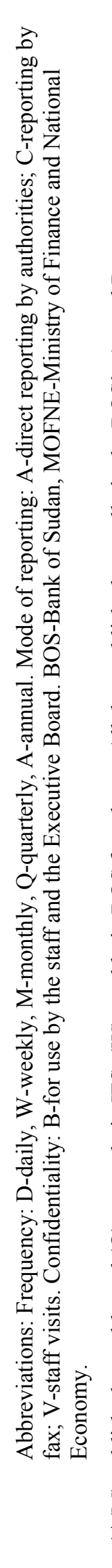 } \\
\hline 苍艺 & बे & ڤั & $\varangle$ & $\varangle$ & 《焉 & 3 & 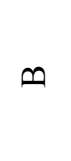 & $\varangle$ & \\
\hline 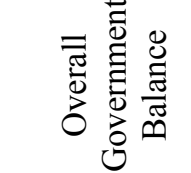 & 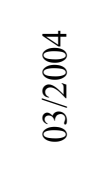 & 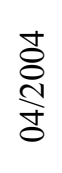 & $\Sigma$ & $\Sigma$ & 《焉 & 0 & 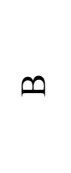 & $\Sigma$ & \\
\hline 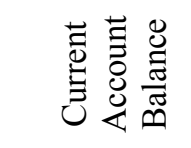 & 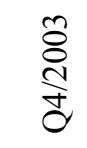 & 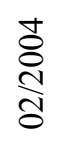 & $\alpha$ & 0 & 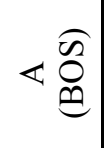 & 3 & $\infty$ & 0 & \\
\hline 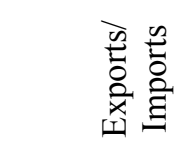 & 灾 & 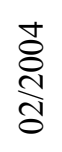 & $\Sigma$ & $\Sigma$ & $\varangle \stackrel{\widehat{\tilde{O}}}{\tilde{\theta}}$ & $u$ & $\infty$ & $\Sigma$ & \\
\hline 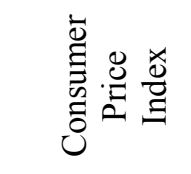 & 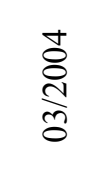 & 辛 & 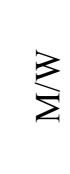 & $\Sigma$ & 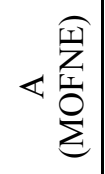 & 0 & 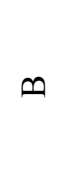 & $\Sigma$ & \\
\hline 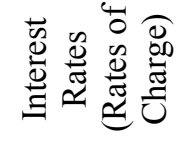 & 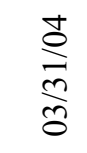 & 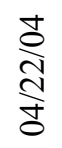 & 3 & $\Sigma$ & $\begin{array}{l}\widehat{0} \\
\ddot{\theta}\end{array}$ & $u$ & 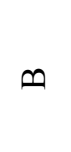 & $\sum$ & \\
\hline 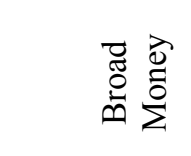 & $\frac{d}{\stackrel{d}{\infty}}$ & 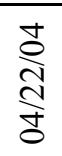 & 3 & 3 & $\varangle \stackrel{\widehat{\theta}}{0}$ & $\begin{array}{l}\overline{\widetilde{\pi}} \\
\text { है } \\
0\end{array}$ & 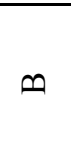 & $\Sigma$ & \\
\hline 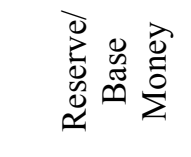 & 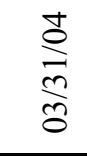 & $\begin{array}{c}\frac{9}{4} \\
9 \\
4 \\
4 \\
4\end{array}$ & $\Sigma$ & 3 & $\begin{array}{l}\widehat{0} \\
\tilde{\theta}\end{array}$ & $\begin{array}{l}\overline{\overline{\widetilde{J}}} \\
\overline{0} \\
\end{array}$ & 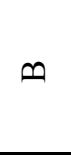 & $\Sigma$ & \\
\hline 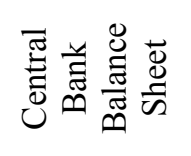 & $\frac{d}{\stackrel{2}{\infty}}$ & 辛 & $\Sigma$ & $\Sigma$ & $\varangle \hat{\tilde{0}}$ & 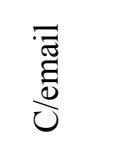 & 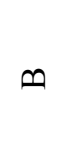 & $\Sigma$ & \\
\hline 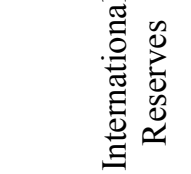 & $\frac{d}{\frac{d}{2}}$ & 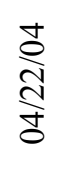 & $\Sigma$ & $\Sigma$ & $\begin{array}{c}\widehat{0} \\
\hat{\theta}\end{array}$ & $u$ & 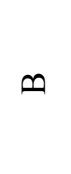 & $\Sigma$ & \\
\hline 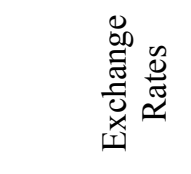 & $\frac{+}{0}$ & $\begin{array}{l}\text { t } \\
\text { oे } \\
\text { है }\end{array}$ & $\theta$ & $\theta$ & $\varangle \widehat{0}$ & 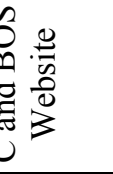 & 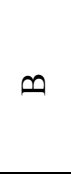 & 0 & \\
\hline & 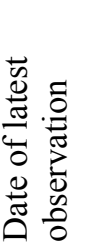 & 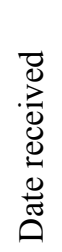 & 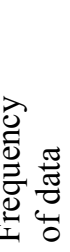 & 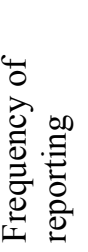 & 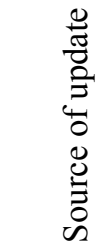 & 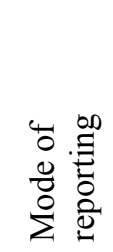 & 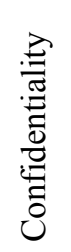 & 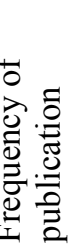 & \\
\hline
\end{tabular}




\section{SUDAN: STRENGTHENING EXTERNAL DEBT MANAGEMENT ${ }^{26}$}

Ensuring long-term debt sustainability-by keeping debt level and new borrowing prudent and using external financing for poverty-reducing and growth-enhancing investment-should be the basis of external debt management in Sudan. The two main challenges in the period ahead are to improve external debt management capacity and follow appropriate borrowing policies. The following key actions should be undertaken:

(i) preparation of a legal and institutional framework for debt management and borrowing policies; (ii) coordination with macroeconomic policies; (iii) a strategy on new borrowing; and (iv) improvement in basic debt management functions and the associated technical capacity.

While the building blocks of external debt management exist, Sudan needs a legal basis to clarify the responsibilities of, and coordination among the, various debt management agencies. The MOFNE, BOS, and the Ministry of International Cooperation all share external debt management responsibilities, but there is no explicit law governing the relationship. ${ }^{27}$ The External Debt Unit (EDU), established in 2000, collects and reconciles information on sovereign debt; prepares quarterly reports for BOS and the MOFNE; publishes a comprehensive annual report; and participates in debt rescheduling negotiations, the formulation of a borrowing strategy, and the assessment of the repayment terms of new loans. The MOFNE's International Cooperation Department is responsible for contracting new borrowing, monitoring disbursements, initiating debt service payments (executed by BOS), and preparing debt service estimates for the budget, in cooperation with the EDU.

Along with a coherent new borrowing strategy, the capacity to analyze the interactions between fiscal, monetary and exchange rate policies, and external financing needs to be developed. A coherent strategy is needed to ensure that new borrowing is suitably concessional, appropriately prioritized, and developed using a medium-term horizon. Highlevel political involvement is needed to set borrowing ceilings, appropriate loan terms, and project selection. Coordination between debt management and macroeconomic policy is the responsibility of the MOFNE and BOS, but has hitherto been limited. An analysis of the costs and potential risks of foreign borrowing needs to be further developed in cooperation with the MOFNE, BOS, and the EDU, under the auspices of a new high-level committee.

While progress has been made in strengthening some basic debt management functions, Sudan's debt management capacity needs to be built up over time and available resources focused on meeting the most immediate challenges. These include:

\footnotetext{
${ }^{26}$ Summary of aide-mémoire for the authorities prepared by the mission.

${ }^{27}$ The 1977 Financial and Accounting Regulation and Procedures Act grants the minister of finance sole authority to approve new loans and guarantees.
} 
- $\quad$ establishing a high-level debt policy and monitoring committee to formulate and implement policy on external borrowing. The committee, comprising MOFNE and BOS representatives and chaired by a state minister, should propose annual external borrowing ceilings within a multiyear rolling budget, establish guidelines for appropriate loan terms, review loan proposals for the minister of finance, and coordinate debt rescheduling and relief negotiations with creditors;

- $\quad$ strengthening technical capacity for loan evaluation and debt sustainability assessment. The debt policy and monitoring committee should draw, as required, on the resources of the various departments of the MOFNE and the EDU. A possible division of tasks would be for the former to provide technical support for loan evaluation and the latter to help assess debt service implications of new borrowing;

- $\quad$ making preparations to negotiate and implement Heavily Indebted Poor Countries (HIPC)-related debt rescheduling and relief agreements with Sudan's multilateral and bilateral creditors. The expertise already available in the MOFNE's Department of International Cooperation and the EDU should be developed further, and technical assistance could be sought, as needed. The Fund and the Bank could assist in the preparation of debt sustainability analyses for the HIPC Initiative, but others, including the United Nations Conference on Trade and Development (UNCTAD) and Debt Relief International, could also provide specialized assistance. 
Khartoum, May 22, 2004

Ms. Anne O. Krueger

Acting Managing Director

International Monetary Fund

Washington, D.C. 20431

Dear Ms. Krueger:

We have completed our discussions with Fund staff on the final review of the 2003 staffmonitored program (SMP) concluding that we have successfully implemented the objectives of the program. We have also reached agreement on a strong SMP for 2004 with policy content that, we believe, is equal in strength to a rights accumulation program (RAP). The government believes that the policies set forth in the attached Memorandum of Economic and Financial Policies (MEFP) are adequate to achieve the objectives of the program.

We are fully committed to implementing the program policies, and we will take further measures that may become appropriate for this purpose. Sudan will consult with the Fund on the adoption of these measures and in advance of revisions to the policies contained in the MEFP, in accordance with the Fund's policies on such consultation.

We look forward to the Executive Board's discussion of our performance under the 2003 SMP and endorsement of the strength of our policies under the 2004 SMP. We will also redouble our efforts with international creditors to obtain financing assurances for debt relief under the Heavily Indebted Poor Countries (HIPC) framework and, thus, allow Sudan to move expeditiously to a RAP. However, in the event that such assurances are delayed, we would like the Fund to explore other options to resolve Sudan's arrears with the IMF in a timely manner to allow the normalization of Sudan's financial relation with its international creditors and the resumptions of external financial assistance. Without the latter, a significant financing gap will emerge once the peace agreement is concluded, which in turn will undermine the post-conflict recovery.

We will increase our yearly payment to the IMF to $\$ 30$ million, but note the need to review the situation after a peace agreement is signed. We hope that both the Board and management will, at that time, take into consideration the need to finance new commitments arising from the peace agreement, and accordingly the need to revise downwards such payments.

Sincerely yours,

$/ \mathrm{s} /$

Al-Zubeir Ahmed Al-Hassan

Minister of Finance and National Economy

Ministry of Finance and National Economy
$/ \mathrm{s} /$

Sabir Mohamed Hassan

Governor

Bank of Sudan

Attachment: Memorandum of Economic and Financial Policies 


\section{SUDAN}

\section{Memorandum of Economic ANd Financial Policies}

1. This memorandum reviews the outcome of the 2003 Staff-Monitored Program (SMP), outlines the economic program for 2004, and sets out our medium-term policy objectives.

\section{ReCENT MACROECONOMIC AND Policy DeVelopments}

2. The economic outcome in 2003 was broadly in line with program projections, and all quantitative targets for end-December (except for that on nonconcessional external borrowing) were met. Rapid growth in agriculture (6 percent), utilities (electricity and water at 4.9 percent), and services (6.2 percent) contributed to the slightly higher-than-projected real GDP growth of 6 percent. Growth in the oil sector remains strong ( 13 percent), though slightly lower than previously projected (13.3 percent). Consumer price inflation fell from 8.3 percent in 2002 to 7.7 percent in 2003, but was above the program target of 7 percent.

3. The balance of payments strengthened substantially in 2003, with the current account deficit (on a cash basis) falling to 4.9 percent of GDP, compared with 6.2 percent in 2002 . The strong growth in investment goods imports was more than offset by the increase in export receipts, especially from petroleum, cotton, and hides. Remittances and private capital inflows, including foreign direct investments (FDI), increased sharply, thereby financing the current account deficit and allowing a significant buildup of international reserves. The Bank of Sudan's (BOS) usable reserves rose to $\$ 527$ million (equal to 1.8 months of imports), well above the program target of $\$ 456$ million. The foreign exchange market remained stable in 2003 , and the nominal exchange rate appreciated by 1 percent.

4. The fiscal outcome in 2003 was better than expected. The overall fiscal balanceexcluding the Oil Savings Account (OSA) —was +0.2 percent of GDP. Non-oil revenues were broadly in line with the program projections. Higher-than-expected production and prices drove oil revenues above program projections by 3.3 percent of GDP. Total expenditures exceeded the program target because of emergency spending for flood relief in eastern Sudan and humanitarian aid and security-related outlays in western Sudan during the second half of the year. Higher oil prices also allowed faster accumulation of reserves in the OSA which rose by $\$ 135$ million in 2003 to $\$ 175$ million.

5. Broad money growth accelerated in the latter part of 2003 and reached 30 percent by the end of the year, compared with the program target of 23 percent. Reserve money also rose at a strong pace of 27 percent, despite substantial open-market sales of government securities and foreign exchange by BOS toward the end of 2003. The rapid monetary growth was fueled by large capital inflows, higher-than-expected government spending, and increased lending by BOS in support of agriculture finance. 
6. With respect to structural reforms in the fiscal area, progress was achieved in strengthening the tax system, including launching a program to reform the direct tax system and establishing a large taxpayer unit. In addition, a number of steps were taken to reform the tax incentive regime of the Investment Encouragement Act (IEA), including tightening exemption criteria, centralizing the authority to grant exemptions, and setting limits on renewing exemptions. Some progress was also achieved in developing a medium-term budget framework and a consolidated three-year rolling budget that was prepared in the context of the 2004 budget. However, progress with respect to improving expenditure management and fiscal reporting was limited, in part because of capacity constraints. Technical difficulties also prevented the timely audit of the Sudan Petroleum Corporation (SPC) subsidiaries and the consolidation of their accounts.

7. All monetary structural reform measures were implemented in 2003. A monetary operation unit (MOU) was established at the BOS to conduct open market operations; a new government security, the Government Investment Certificates (GICs), was launched; the laws governing the central bank and banking activities were amended by parliament to, among other things, establish central bank independence and strengthen banking regulations; and an anti-money laundering law was enacted. With Fund technical assistance, a study examining the possibility of introducing market-based agricultural finance hedging instruments was completed.

\section{OUTLOOK AND POLICIES FOR 2004}

8. The program and structural reform agenda for 2004 will build on the considerable success of the past seven years in achieving and maintaining macroeconomic stability. The envisaged policies and structural reforms are also intended to strengthen the policy stance, and the conduct of economic policy institutions is intended to better meet the challenges of the post-conflict environment.

9. The program envisages 6.6 percent of real GDP growth in 2004 supported by a strong expansion in the oil, construction, and utilities sectors. Inflation is expected to fall to 6.5 percent. Continued high capital inflows and strong export performance will further improve the external position, allowing the international reserve buildup to reach \$807 million (2.5 months of imports), including \$210 million of additional OSA accumulation. The external current account deficit (on a cash basis) is expected to increase slightly to 5.2 percent of GDP in 2004, reflecting a rapid growth in project-related imports, which will be partly offset by a continued expansion of oil exports and the recovery of nonoil exports.

\section{Fiscal}

10. We will continue to pursue prudent fiscal policy in 2004. The overall deficit is expected to reach 1.2 percent of GDP, reflecting an increase in foreign-financed development projects, including the Merowe dam project. Despite the continued savings of oil revenues in the OSA and strengthened tax revenue, the non-oil domestic budget deficit is expected to rise 
moderately because of an increase in oil production and higher international oil prices. Domestic financing of the deficit (excluding the accumulation of deposits in the OSA), will be limited to SDD 44 billion ( 0.9 percent of GDP), consistent with the restrained monetary program.

11. Expenditure policy in 2004 will aim to increase social outlays by 54 percent to SDD 86 billion (1.7 percent of GDP) in 2004, especially in the area of health, education, water, and agriculture. Military spending is budgeted to remain broadly unchanged in 2004 compared with 2003 at about 2.5 percent of GDP. The 2004 budget also envisages a wage increase of 50 percent, which includes an increase in the minimum wage from SDD 7,500 per month to SDD 12,500 per month. We believe that this step is necessary as public sector wages have lagged considerably behind the private sector in recent years, affecting the ability of the public sector to attract qualified staff. Furthermore, we expect the increase in the minimum wage to contribute to poverty reduction.

12. As part of our continued efforts to raise non-oil revenue and streamline tax exemptions, we undertook several measures in the 2004 budget that we expect to yield SDD 44.7 (0.9 percent of GDP). These measures include (i) applying an excise tax on petroleum products; (ii) raising the excise tax on sugar from 14 percent to 17 percent; (iii) introducing steps to enforce the collection of departmental fees; (iv) raising the selling price of crude oil to refineries; and (vi) abolishing the corporate tax exemptions for rehabilitation purposes.

13. To ensure the availability of adequate resources to support the peace, we will submit to parliament, following the conclusion of the peace agreement, an amended budget for 2004 that will mobilize the necessary resources to meet the obligations of the agreement. We intend to reduce immediately the wage bill in 2004 by SDD 22 billion ( 0.4 percent of GDP) and propose the following additional revenue measures, which we expect to generate more than SDD 10 billion ( 0.2 percent of GDP) on half-year basis:

a. raising the petroleum excise tax;

b. imposing a turnover development tax of 1 percent on all tax-exempt entities with no exemptions provided;

c. considering applying an excise tax on mobile communication services and eliminating all other fees and charges;

d. applying the value-added tax (VAT) on capital goods imports and domestic sales;

e. eliminating the 10 percent privilege tax rate on the income of professionals.

14. In the event that some or all of the revenue measures are not approved by parliament, we intend to further reduce expenditures across most budget sectors to generate the savings 
necessary to cover the revenue shortfall, while protecting social and key development programs as approved in the 2004 budget.

15. As part of our continued efforts to streamline tax exemptions, we intend to enforce a ban, through a ministerial decree distributed to all line ministries, on all discretionary tax exemptions by end-April. In addition, we intend to complete a review of all regulations and agreements, which result in tax exemptions, and develop an action plan to streamline them in the context of the 2005 budget by end-December 2004. In addition, the tax privileges of the four major oil distribution companies will not be renewed after they lapse at the end of 2004, and no new exemptions will be granted to other companies.

16. With respect to improving expenditure management and fiscal reporting, we will concentrate in 2004 on establishing an effective cash management system at the ministry of finance, improving fiscal reporting, and initiating the process of adopting a functional and economic budget classification system. We believe that these steps are essential to improve fiscal performance and that they would support the post-conflict fiscal environment.

17. To improve the cash management system, we intend, by end-April 2004, to fully constitute the cash management unit (CMU) (including issuing the relevant ministerial decree for the respective institutional and regulatory changes), appoint a cash release committee, and draft an action plan based on the recommendations of the upcoming Fund technical assistance mission. By end-June 2004, the CMU will prepare a fiscal budget cash plan on a monthly basis for the second half of the year, approve the cash plan by the cash release committee, and present the approved cash plan to the BOS. To ensure the transparency and effectiveness of cash management, we will abolish all tax netting operations related to direct taxes and VAT certificates by end-June. With regards to the VAT collected by the customs, we will make the necessary administrative changes so that payments are made to the taxation chamber and transferred on a weekly basis by end-April and on a daily basis by end-June.

18. An action plan to strengthen the fiscal reporting system will be developed by end-April 2004. As a first step, we will begin preparing monthly fiscal reports within 2-3 weeks after the end of each month. To keep the process of timely reporting sustainable, we will incorporate in the action plan concrete measures for improving overall coordination in preparing monthly accounts, further computerization of the government accounting system, and training of budgetary accountants.

19. A two-year program to align the budget classification with the government finance statistics (GFS) will be adopted by end-April 2004. The program will entail the following key benchmarks: (a) classifying, as a technical exercise, the 2004 budget sectors into the GFS functions by end-June 2004; (b) preparing the 2005 budget presentation according to the functional classification of expenditures in addition to the traditional presentation by sectors; (c) implementing the 2005 budget in some pilot ministries on the base of the old and the new classification; and (d) fully adopting the GFS classification with the 2006 budget. 
20. Tax administration reforms will focus on three areas: (a) ensuring that the large taxpayer unit will be fully operational by end-June 2004 and broadening the definition of large taxpayers to include individuals by end-2004; (b) adopting a universal taxpayer identification number, including on excise duties by end-June 2004; and (c) launching a pilot project in audit enforcement to increase field audits. In the area of customs reform, a more selective risk-based verification system will be implemented through the nationwide coverage of the Automated System for Customs Data (ASYCUDA)++ system.

21. The OSA mechanism has been instrumental in building up international reserves and rationalizing the use of oil revenues. The 2004 budget was prepared based on an OSA oil price benchmark of $\$ 22$ per barrel. However, given that Sudan oil export prices are now projected to average over $\$ 28$ per barrel, we will raise the benchmark price to $\$ 24$ per barrel and save the oil revenues arising from international oil prices above benchmark. We are committed to allocating SDD 11 billion from the extra revenue generated by raising the OSA benchmark price on additional social spending programs.

\section{Monetary and exchange system}

22. Monetary policy will target a broad money growth rate target of 22 percent for 2004, which is consistent with the GDP growth and inflation objectives, as well as some decline in velocity. The monetary target and the projected buildup in foreign reserves should allow for an appropriate growth rate of credit to the nongovernmental sector. Additional attention will be focused on BOS's lending to banks to ensure that it is consistent with the monetary target. In addition, the BOS will assist, if necessary, in managing, but not extending, the financial support provided by the government to agriculture, given the underdevelopment of the agriculture finance infrastructure in Sudan at present. The conduct of monetary policy will continue to rely on indirect monetary instruments, and no restrictions will be imposed on market financing rates and banks' credit allocations. The broad money growth target will be reassessed during the program reviews to ensure that it remains in line with the program's macroeconomic objectives.

23. To improve the conduct of monetary policy, the recently established MOU will be transformed by end-September 2004, with Fund technical assistance, into a monetary operations division (MOD) - to execute the policy guidelines established by the monetary policy committee (MPC). In coordination with the planned CMU of the ministry of finance, the MOD will issue daily instructions to the relevant BOS operations departments (foreign exchange, government securities, and standing credit facilities) on the extent of foreign exchange and securities transactions, as well as the size of liquidity emissions from the standing credit facilities.

24. To support the operations of the MOD and enhance the flash reporting system, a database will be established and maintained on a daily basis. The database will include, inter alia, daily bank deposits; required reserves and excess reserves; banks' foreign exchange positions; estimates of banks' vault cash, currency in circulation and bank float; government accounts held with the central bank; bank holdings of government and BOS securities; bank 
lending; and the various rates in the market. Only with such a database can the BOS begin to forecast these items daily for the two-week period that the MPC can review in forming its directions for indirect monetary operations.

25. We will continue to maintain a foreign exchange system that is free from restrictions on current account transactions in accordance with our acceptance of the obligations of Article VIII, Sections 2, 3, and 4 of the Fund's Articles of Agreement. We remain committed to implement a managed-float exchange rate regime. The exchange rate will be allowed to adjust reflecting prevailing economic conditions, and the BOS's intervention will be limited to ensuring a stable foreign exchange market and orderly exchange rate adjustment. However, we recognize the need to increase the flexibility of the exchange system and to better align foreign exchange operations within the money-targeting framework.

Accordingly, the intraday market exchange rates will be allowed, by end-December 2004, to fluctuate within \pm 3 percent from the previous day average market rate instead of the present \pm 2 percent. In addition, the BOS's foreign exchange interventions will be primarily guided by monetary policy considerations during periods when exchange rate movements remain within the permitted daily fluctuations range.

\section{Trade and external debt}

26. We intend to maintain our current open nontariff trade system. We will also develop, by end-December 2004, a new three-year tariff reform program that will be implemented in the context of the 2005 budget. The new program will aim at reducing the average tariff rate and the number of tariff bands. Given the substantial resources needed to support peace and poverty reduction, the tariff reforms will be coordinated with the ongoing efforts to improve tax revenue.

27. Sudan's progress toward WTO accession has been significant, as noted by members of the Second Working Party (WP) during the March 10, 2004 meeting. All necessary documents have been submitted to the WTO, except the initial offer documents on goods and services, which we expect to submit by May 2004. As a least developed country, Sudan has asked for special and differential treatment on various accession issues, including on the granting of transitional periods and the provision of technical assistance. We have requested the WTO Secretariat to start preparing the factual summary that would form the basis of the draft WP report and consolidate the progress achieved.

28. Strengthening external debt management capacity will be an important objective for this year. Accordingly, by end-December 2004, an external debt policy of the public sector will be formulated and approved by the cabinet of ministers, and a three-year rolling ceiling on the contracting of new external debt will be prepared, in the context of the 2005 budget, in line with the repayment capacity and overall debt sustainability objective in the context of the debt relief under the HIPC Initiative. In addition, a Debt Policy and Monitoring Committee will be established by end-April 2004 to guide the formulation and implementation of the debt policy and to evaluate all new loans before they are approved by the ministry of finance. Furthermore, the technical and human resources of the BOS's External Debt Unit will be 
strengthened in order to enhance Sudan's preparedness for negotiating and implementing debt rescheduling and relief operations in the context of the HIPC Initiative.

\section{Other reforms}

29. To improve the transparency of the oil sector, we plan to audit and consolidate the accounts of all SPC subsidiaries and launch a program to align their accounting systems with international standards. To facilitate this plan, an action timetable will be prepared by endApril 2004.

30. The privatization program has been proceeding at a reasonable speed and has been attracting the interest of foreign investors. Gross privatization proceeds are expected to reach SDD 15.7 billion in 2004 compared with SDD 9 billion in 2003, reflecting a government sale of part of its shares in the Bank of Khartoum and Sudan Airways Company, and the sale of the Rabak Cement Factory.

\section{MEDIUM-TERM OUTLOOK}

31. With the overall objective of achieving robust post-conflict growth and poverty reduction over the medium term, we plan to pursue prudent macroeconomic policies and structural reforms that will lead to private sector-led non-oil growth. The medium-term strategy aims at achieving 6-7 percent of GDP growth and targets an inflation rate of 5-6 percent. The current account deficit is expected to average about 6 percent of GDP, and international reserves are targeted to rise to about 3-4 months of imports. The domesticallyfinanced budget deficit will be kept at or below 1 percent of GDP, consistent with the overall macroeconomic framework. Monetary policy will aim to support the inflation target, and a flexible managed-float exchange rate will be maintained.

32. With peace, we foresee a resolution to Sudan's external debt problems and an improvement in our relations with the international community. The relaxation of external financing constraints, in conjunction with an expected increase in oil production and higher FDI along with new revenue measures, will enable the country to undertake a higher level of investments. These positive factors will more than offset the following constraints arising from the peace agreement over the medium term. First, transfers to the South would have to be increased in line with its share of oil revenues, resulting in a net increase in transfers from the federal budget to states of about 12 percent of total revenues. Secondly, the demobilization of armed forces following the peace agreement will require net budgetary expenditures in the first three years before savings accrue on account of downsizing of the military. The challenge over the medium term would be to ensure sufficient private sector-led growth and employment generation, while allowing adequate budgetary allocations for poverty reduction.

\section{RELATIONS WITH THE FUND AND OTHER CREDITORS}

33. We remain committed to regularizing relations with all our creditors, and, in particular, strengthening Sudan's relations with the Fund. Sudan made regular payments to 
the Fund as committed to under the 2003 SMP (\$27 million), and we hope that our record of cooperation will be fully recognized. Notwithstanding that the demands of peace in 2004 will likely place a considerable burden on the resources of the government of Sudan and balanceof-payments uncertainties, we will increase our payments to the Fund to \$30 million in 2004.

34. We made significant progress in regularizing relations with external creditors. Agreements have been reached with a number of bilateral Arab funds and most of the multilateral creditors, including the World Bank, African Development Bank, Islamic Development Bank, International Fund for Agricultural Development, Arab Fund for Economic and Social Development, OPEC Fund for International Development, and Arab Monetary Fund. These agreements have resulted, in most cases, in net financing inflows. We will also intensify our efforts towards reaching an agreement with the remaining multilateral creditors. Finally, we will work closely with a support group of creditors led by the United Kingdom to secure the support of donors for resolving our external debt problem under the HIPC Initiative.

\section{Program Monitoring}

35. Proposed semiannual quantitative indicative targets for the periods of end-June and end-December 2004 are set forth in Table 1, and the structural benchmarks are detailed in Table 2. We will closely monitor financial and economic developments in the coming months and will, in consultation with Fund staff, implement any measures that may be needed to safeguard macroeconomic stability. 
Table 1. Sudan: Quantitative Indicative Targets, 2004

(In billions of Sudanese dinars; unless otherwise indicated)

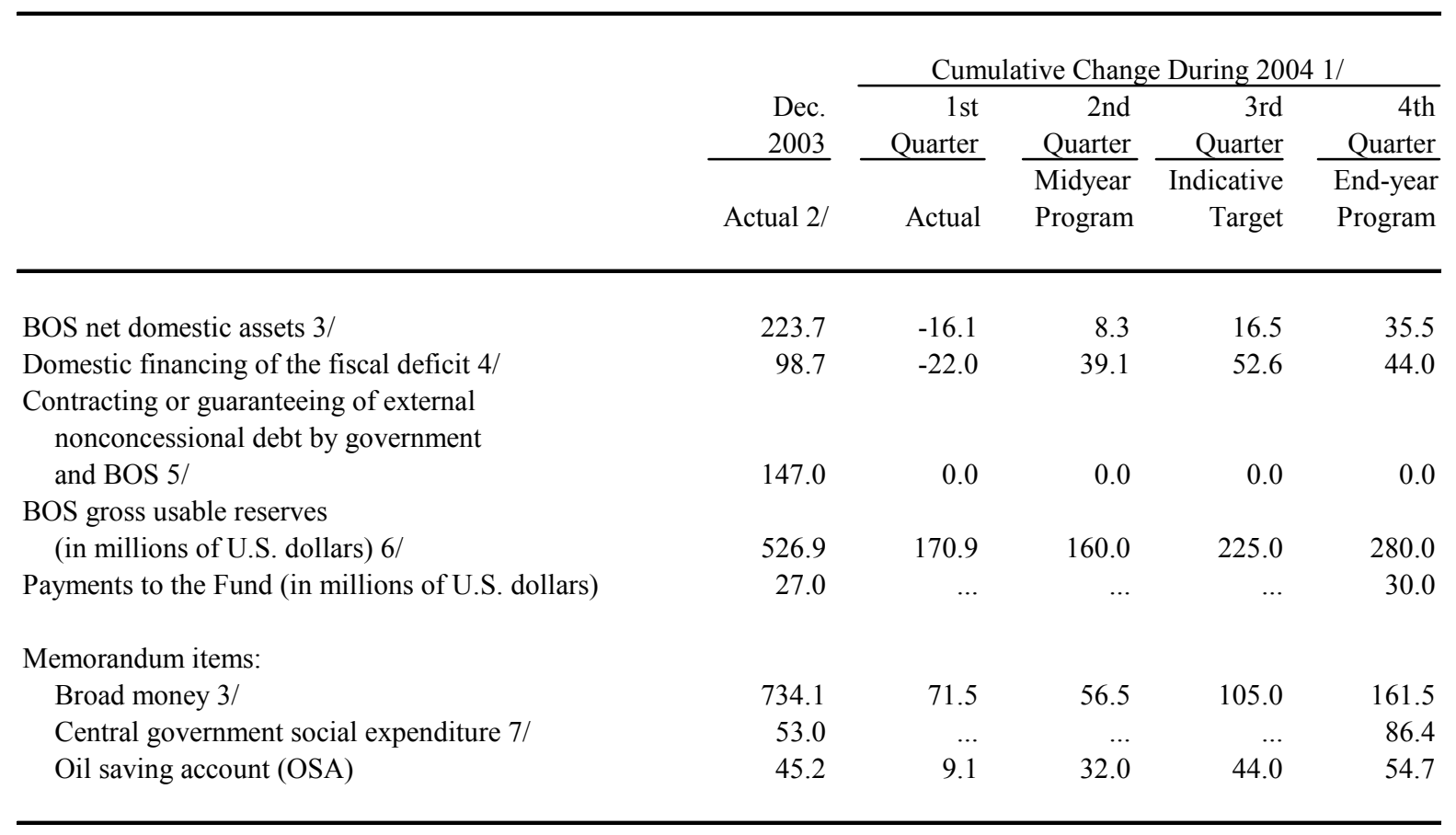

Sources: Sudanese authorities; and Fund staff estimates and projections.

1/ Cumulative change from end of the previous year.

2/ Outstanding stock at end-of-year.

3/ Based on new presentation of the monetary data, consistent with Fund guidelines, adopted in January 2000. Net BOS financing is defined as borrowing by the government from the BOS (including GMCs) minus central government deposits at the BOS (excluding deposits accumulated in the OSA).

4/ Defined as total net borrowing by the government, including net borrowing from the BOS (including GMCs and changes in deposits of the central government with the BOS), net sales of GMCs outside the BOS, revenues from privatization, and repayments of internal domestic debts.

5/ This indicative target applies not only to debt as defined in point No. 9 of the Guidelines on Performance Criteria with Respect to Foreign Debt (Decision No. 12274 - (00/85), August 24, 2000), but also to commitments contracted or guaranteed, for which value has not been received. Debt will be deemed to be concessional when the currency-specific discount rate (determined by the market-related "commercial interest reference rates (CIRR)" as published by the OECD) applied to the contractual schedule of charges and principal payments, indicates a grant element of at least 35 percent. The indicative target excludes the financing of the Merowe hydropower project.

6/ In the new presentation of the Monetary Authorities' Accounts, gross usable reserves include foreign banknotes in the vaults of the BOS.

7/ Central government expenditure on medical care; health services; poor students' support; supplement to poor consumers of electricity; social and health insurance; water, health, and education development. 
Table 2. Sudan: Structural Benchmarks for 2004

\section{Policy Area}

Prior Actions

1. Enforce a ban, through a ministerial decree distributed to all line ministers, on all discretionary tax exemptions.

2. Constitute the cash management unit (CMU), appoint a cash release committee, and draft an action plan to operationalize the CMU.

3. Adopt a two-year program to align the budget classifications with the GFS.

4. Develop an action plan to reform the fiscal reporting system.

5. Establish a Debt Policy and Monitoring Committee to guide the formulation and implementation of a debt strategy and to evaluate all new loans.

6. Prepare a time-bound action plan to audit and consolidate the accounts of all subsidiaries of Sudan Petroleum Corporation, and launch a program to align their accounting system with international standards.

By end-June 2004

1. Prepare a fiscal budget cash plan on a monthly basis for the second half of 2004. The cash plan must be approved by the cash release committee and presented to the Bank of Sudan (BOS).

2. Begin to transfer VAT collected by customs to the taxation department on a daily basis.

3. Activate the large tax payer unit.

4. Classify, as a technical exercise, the 2004 budget sectors into the GFS.

5. Adopt a universal taxpayer identification number.

By end-December 2004

1. Complete a review of all regulations and agreements that grant tax exemptions and develop an action plan to streamline the regulations in the context of the 2005 budget.

2. Broaden the definition of large taxpayers to include individuals.

3. Eliminate all tax privileges of the four major oil distribution companies.

4. Develop a new three-year tariff reform program that will be implemented in the context of the 2005 budget.

5. Formulate an external debt policy of the public sector and have it approved by the cabinet of ministers. 


\section{SUDAN}

\section{TECHNiCAL MEMORANDUM OF Understanding}

1. This memorandum specifies the understanding reached with the Fund staff regarding the quantitative benchmarks and indicative targets for the 2004 Staff-Monitored Program (SMP).

2. The 2004 SMP relies on five quantitative quarterly indicative targets and an oil revenue adjustor. The quantitative indicative targets are (i) ceilings on net domestic assets of the Bank of Sudan (BOS); (ii) ceilings on the domestic financing of the fiscal deficit; (iii) floors for the buildup of gross usable reserves of the BOS; (iv) ceilings on new nonconcessional external loans contracted or guaranteed by the government; and (v) floors for payments to the Fund. Broad money, floor for the central government social expenditures, and oil savings account (OSA) will be monitored as memorandum items. All indicative targets are presented in Table 1, Attachment I.

3. The relevant definitions for the quantitative indicative targets and the oil revenue adjustor are set out hereafter.

4. Net domestic assets (NDA) of the BOS are defined as the sum of the Net Domestic Credit of the BOS, the net issue of money market instruments central bank musharaka certificates (CMCs), and other items net (OIN) of the BOS.

5. The Net Domestic Credit of the BOS is defined as total credit to the central government (including government musharaka certificates (GMCs) and government finance certificates (GFCs)) minus total central government deposits with the BOS plus BOS claims on public enterprises plus BOS claims on banks. The definition of the central government comprises all accounts of the line ministries and agencies controlled by them (corresponding to Group no. 11, Group no. 12, and some accounts of the Group no. 19 in the BOS general ledger), the Zakhat funds (recorded under Group no. 13), and margin deposits placed with BOS by the central government against letters of credit issued by the BOS. The definition includes all oil-related accounts controlled by the government.

6. Net issues of CMCs by the BOS are classified as part of the NDA, in accordance with Fund standards, to facilitate the effects of money-market operations on a monetary base.

7. The identification of all accounting balances recorded under OIN has been established with the help of the IMF's Statistics Department mission that visited Khartoum in May 2000 and is detailed in the corresponding mission report.

8. Domestic financing of the fiscal deficit is defined as total net domestic borrowing by the central government, including net borrowing from the banking system (including GMCs and GFCs), but excluding deposits accumulated in the OSA; net sales of GMCs and GFCs outside the banking system; revenues from privatization; and repayments by the 
central government of internal domestic debts to public agencies, banks, and private companies. The definition of central government for the purpose of this criterion is the same as the one applied for the NDA of the BOS.

9. BOS gross usable reserves are foreign reserve assets, as defined in the balance-ofpayments manual, that are controlled by the BOS, are immediately and unconditionally available to the BOS for meeting balance-of-payment needs, and are not earmarked by the BOS for meeting specific payments. They consist of balances on accounts maintained with overseas correspondent banks and foreign exchange banknotes in the vaults of the BOS.

10. Contracting or guaranteeing of new nonconcessional external debt by the government applies not only to debt as defined in point no. 9 of the Guidelines on Performance Criteria with Respect to Foreign Debt (Decision no. 12274-(00/85), August 24, 2000), but also to commitments contracted or guaranteed, for which value has not been received. Debt will be deemed to be concessional when the currency-specific discount rate (determined by the market-related "commercial interest reference rates (CIRR)" as published by the OECD) applied to the contractual schedule of charges and principal payments, indicates a grant element of at least 35 percent.

11. Broad money is defined as the sum of local currency circulating outside of the banks, banks' demand, and time and savings deposits. It also includes transferable deposits and margin deposits against letters of credit placed by the local government, nonfinancial public enterprises, and the nonbank private sector with the BOS.

12. The oil revenue adjustor applies as follows: oil revenue arising from an export price of over \$24 per barrel for Nile oil exports, f.o.b. Port Sudan, will be deposited in a government account at the BOS. However, amounts will be transferred, if necessary, to the government, at least on a quarterly basis, to ensure that government oil export receipts are not less than the amounts targeted under the program. The program targets for domestic financing of the budget deficit and BOS NDA will be reduced, and the international reserve target will be raised by amounts corresponding to the accumulated deposits during the program period. In the event of oil revenue shortfalls below the quarterly program targets, the accumulated balance at the BOS can be drawn down to make up the shortfall in revenue; correspondingly, the program targets for domestic financing of the budget deficit and BOS NDA will be raised, and the international reserve target reduced. The adjustor will be reviewed at the regular program reviews.

13. Central government social expenditure corresponds to central government expenses on medical care; health services; poor students' support; supplement to poor consumers of electricity; social and health insurance; and water, health, and education development. 